\title{
B-ALL Complexity: Is Targeted Therapy Still A Valuable Approach for Pediatric Patients?
}

\author{
Stefano Ratti ${ }^{1,+} \oplus$, Annalisa Lonetti ${ }^{2,+} \oplus$, Matilde Y. Follo ${ }^{1}$, Francesca Paganelli ${ }^{1}$, \\ Alberto M. Martelli ${ }^{1}$ (D), Francesca Chiarini ${ }^{3,4, *}$ and Camilla Evangelisti ${ }^{3,4, *}$ \\ 1 Department of Biomedical and Neuromotor Sciences, University of Bologna, Via Irnerio 48, 40126 Bologna, \\ Italy; stefano.ratti@unibo.it (S.R.); matilde.follo@unibo.it (M.Y.F.); francesca.paganell16@unibo.it (F.P.); \\ alberto.martelli@unibo.it (A.M.M.) \\ 2 Giorgio Prodi Cancer Research Center, S. Orsola-Malpighi Hospital, University of Bologna, Via Massarenti, \\ 11, 40138 Bologna, Italy; annalisa.lonetti2@unibo.it \\ 3 CNR Institute of Molecular Genetics Luigi Luca Cavalli-Sforza, Via di Barbiano 1/10, 40136 Bologna, Italy \\ 4 IRCCS Istituto Ortopedico Rizzoli, Via Di Barbiano 1/10, 40136 Bologna, Italy \\ * Correspondence: francesca.chiarini@cnr.it (F.C.); camilla.evangelisti@cnr.it (C.E.); \\ Tel.: +39-051-209-1581 (F.C.); +39-051-209-1581 (C.E.) \\ + These authors contributed equally to this work.
}

Received: 16 October 2020; Accepted: 20 November 2020; Published: 24 November 2020

check for updates

Simple Summary: B-ALL is the more frequent childhood malignancy. Even though significant improvements in patients' survival, some pediatric B-ALL have still poor prognosis and novel strategies are needed. Recently, new genetic abnormalities and altered signaling pathways have been described, defining novel B-ALL subtypes.Innovative targeted therapeutic drugs may potentially show a great impact on the treatment of B-ALL subtypes, offering an important chance to block multiple signaling pathways and potentially improving the clinical management of B-ALL younger patients, especially for the new identified subtypes that lack efficient chemotherapeutic protocols. In this review, we shed light on the up-to-date knowledge of the novel childhood B-ALL subtypes and the altered signaling pathways that could become new druggable targets.

\begin{abstract}
B-cell acute lymphoblastic leukemia (B-ALL) is a hematologic malignancy that arises from the clonal expansion of transformed B-cell precursors and predominately affects childhood. Even though significant progresses have been made in the treatment of B-ALL, pediatric patients' outcome has to be furtherly increased and alternative targeted treatment strategies are required for younger patients. Over the last decade, novel approaches have been used to understand the genomic landscape and the complexity of the molecular biology of pediatric B-ALL, mainly next generation sequencing, offering important insights into new B-ALL subtypes, altered pathways, and therapeutic targets that may lead to improved risk stratification and treatments. Here, we will highlight the up-to-date knowledge of the novel B-ALL subtypes in childhood, with particular emphasis on altered signaling pathways. In addition, we will discuss the targeted therapies that showed promising results for the treatment of the different B-ALL subtypes.
\end{abstract}

Keywords: childhood; B-ALL; signaling pathway; target therapy

\section{Introduction}

B-cell acute lymphoblastic leukemia (B-ALL) is a group of blood malignancies that results from the clonal expansion of transformed B-cell precursors, representing around $25 \%$ of all pediatric tumors and more than $80 \%$ of pediatric ALL [1]. 
B-ALL is characterized by recurrent cytogenetic and molecular aberrations, including non-random chromosomal rearrangements, aneuploidy, gene deletions and amplifications [2]. All these alterations may lead to leukemogenesis by interfering with multiple signaling pathways or modulating hematopoietic transcription factors, epigenetic modifiers, cytokine receptors and tyrosine kinases (TK).

B-ALL prognosis in children has considerably been improved over the last few years, with current survival rates exceeding $85 \%$, largely due to intensification of standard chemotherapy and advances in risk classification, supportive care and minimal residual disease (MRD) monitoring, making this one of the main achievements of oncology [3].

The outcome of pediatric B-ALL depends on different factors, such as the elevated heterogeneity at both molecular and clinical levels. Despite this marked heterogeneity, all B-ALL patients are treated with the same chemotherapeutic protocol. Thus, precision medicine approaches intending to increase the cure rate and, at the same time, reduce side effects are needed for B-ALL patients.

Over the last decade, novel approaches have been used to understand the molecular bases of B-ALL, including next-generation sequencing techniques and integrated genomic analyses, identifying new genes and altered signaling pathways with important prognostic and therapeutic significance [4]. These recent findings may impact on B-ALL, by improving the clinical risk stratification and treatment.

New genetic abnormalities, affecting the risk assessment and patients' stratification, have been recently reported, defining novel B-ALL subtypes, characterized by frequent genetic alterations or chromosomal translocations. Some of them were included in the most recent World Health Organization (WHO) classification [5] (Figure 1).

\section{CHILDHOOD B-ALL}

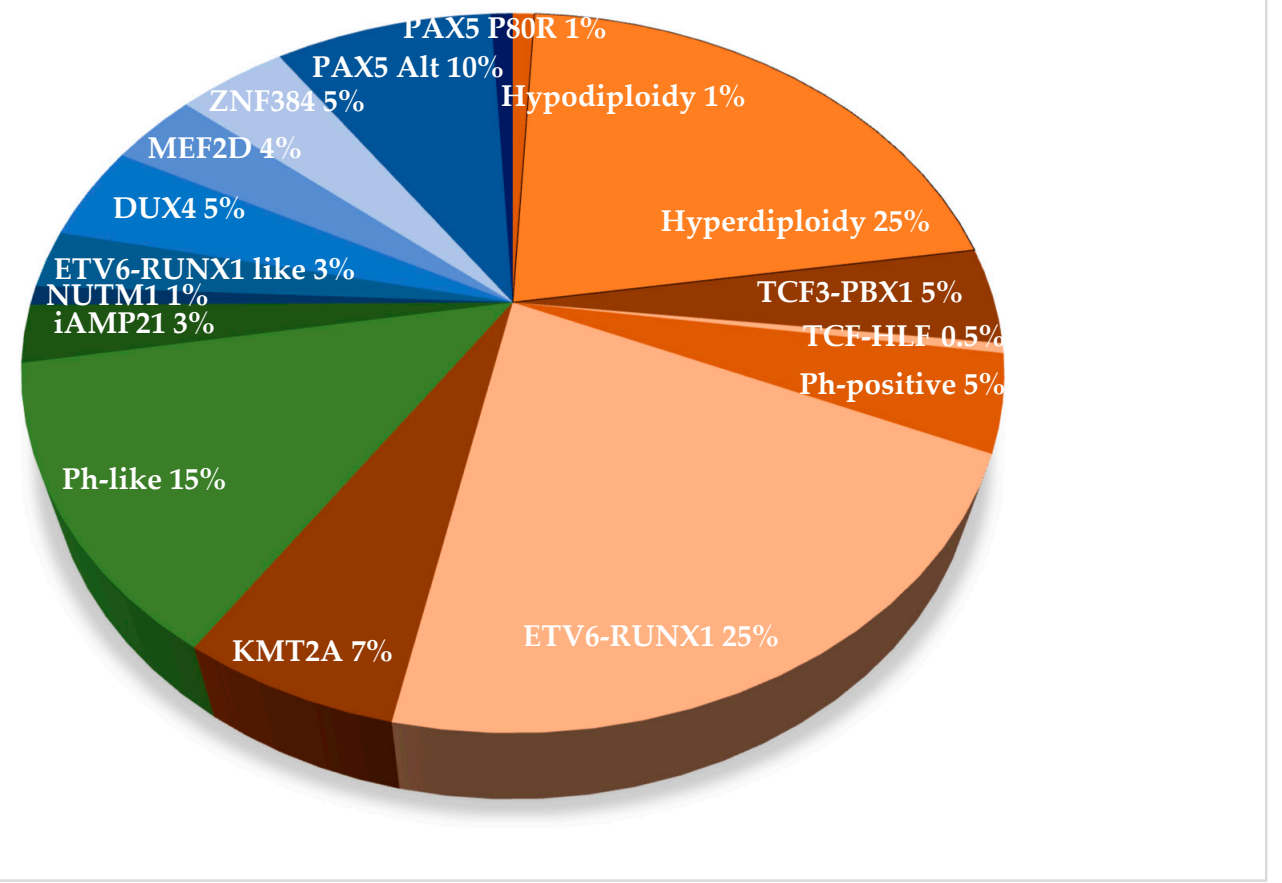

Figure 1. Frequency of childhood B-ALL subtypes. Established subtypes as defined by WHO in 2016 are indicated in orange, provisional entities in green, while new B-ALL subtypes in blue.

In B-ALL, the aberrant proliferation of leukemic cells is correlated with deregulation of pathways and inhibition of different signaling networks, either alone or in association with conventional B-ALL drugs or other targeted therapies, could provide a rationale for the study of novel clinical protocols, particularly in the setting of chemo-resistance. In this scenario, the growing detailed studies of B-ALL 
biology have provided novel opportunities for the development of alternative and more effective therapeutic approaches that may lower the mortality rate and the systemic side effects caused by the chemotherapy currently used in B-ALL treatment.

Here, we will discuss the current state of knowledge of the genetic basis of new B-ALL subtypes, with a particular emphasis on altered signaling pathways.

\section{Aneuploidy B-ALL}

Aneuploidy is referred to the condition of an abnormal number of chromosomes and is one of the most common genetic alterations in pediatric B-ALL, identified several years ago. However, the recent and more precise characterization of B-ALL aneuploidy subtypes led to a better identification of risk stratification and treatment, since masked hypodiploidy could be confused with hyperdiploidy, causing a mistaken classification, a different outcome and, in turn, a treatment failure. Hypodiploidy represents a group of B-ALL with $<44$ chromosomes. Initially identified as a single subtype, it is actually divided into two groups that show distinct mutational profiles and are characterized by different transcriptional profiles and genetic variations: near-haploid ALL ( $<30$ chromosomes) and low-hypodiploid ALL (31-39 chromosomes) [6]. Hyperdiploidy ( $>46$ chromosomes) may be subdivided into low-hyperdiploidy (47-50 chromosomes) [7] and high-hyperdiploidy (51-56 chromosomes) [8].

\subsection{Hypodiploidy}

Near-haploid ALL arises in about $<1 \%$ of pediatric B-ALL while low hypodiploidy occurs in $2 \%$ of cases. The prognosis of both low hypodiploid and near haploid is unfouvarable. Nevertheless, it has been recently demonstrated that low hypodiploid ALL treated within MRD-guided therapy and with good MRD clearance show a better outcome [9].

Near-haploid ALL is characterized by genetic alterations involving Ras signaling pathway, Receptor Tyrosine Kinase (RTK) signaling and IKZF3 [6], whereas CDKN2A/B, IKZF2 and RB1 alterations or TP53 germline mutations are frequently found in low-hypodiploid ALL [10].

A recent study showed that, in a B-ALL patient-derived xenograft (PDX) model, hypodiploid cells are sensitive to the B-cell lymphoma (Bcl) 2 inhibitor Venetoclax (ABT-199), suggesting that Bcl2 inhibition could be a promising strategy for the treatment of hypodiploid B-ALL [6,11].

Importantly, the efficacy of Venetoclax has been already established in chronic lymphocytic leukemia (CLL) and other blood malignancies, showing an acceptable safety profile [12], thus entering into regimens for the treatment of CLL patients [13]. Moreover, Bcl2 inhibitors entered in clinical trials for relapsed or refractory B-ALL patients (NCT03504644, NCT03808610, NCT03181126).

Hypodiploid B-ALL cells exhibit activation of Ras and phosphoinositide-3 kinase (PI3K)/Akt/ mechanistic target of rapamycin (mTOR) signaling pathways and are sensitive to PI3K and PI3K/mTOR inhibitors, suggesting another possible therapeutic approach for both near-haploid and low-hypodiploid B-ALL [6].

The PI3K/Akt/mTOR cascade is hyper-activated in several hematological malignancies [14] and up-regulation of this signaling pathway is related to poor prognosis and glucocorticoids (GC)-resistance [15]. Our group previously reported that NALM-16 near haploid cell line is sensitive to PI3K inhibition, improving GC therapeutic effects and/or overcoming GC-resistance [16].

In addition, selective p1108 inhibitors showed anti-leukemic effects in B-ALL cells and in a B-ALL mouse model [17]. In particular, a p1108-specific inhibitor, GS-649443, was able to extend survival in a mouse xenograft model using near haploid cells and could also synergize with the conventional chemotherapeutic drug Cytarabine [18].

\subsection{Hyperdiploidy}

Hyperdiploidy is observed in approximately $25 \%$ of childhood B-ALL and is associated with a favorable outcome. Ras pathway alterations and epigenetic modifications are frequent events in high-hyperdiploid ALL [8], as well as CEBPE, ARID5B, PIP4K2A, and BMI1 genetic mutations [19-21], 
that are present in 50\% of hyperdiploid patients [8]. Moreover, specific mutations of KRAS that lead to downstream phosphorylation of extracellular signal-regulated kinase (ERK) were found in hyperdiploid patients [8], suggesting that Ras/MEK/ERK network inhibition could be a good therapeutic target in high-hyperdiploid childhood B-ALL. Anyway, these observations warrant further investigations.

Finally, recurrent germline GRB2-associated-binding protein (GAB) 2 mutations were identified in high-hyperdiploid patients and could be evaluated as a putative novel predisposition factor to B-ALL development [21]. Interestingly, GAB2 is an upstream activator of Ras/MEK/ERK and PI3K/Akt/mTOR signaling pathways, though to bind SHP2 and the p85 regulatory subunit of PI3K [22].

\section{Ph-Like B-ALL}

Philadelphia Chromosome-like (Ph-like) ALL is a frequent ALL subtype that comprises up to $15 \%$ of pediatric B-ALL and its incidence increases with age, reaching $25 \%$ of young adults and $20 \%$ of adults with B-ALL $[23,24]$. It is associated with a poor outcome and it has been recognized as a provisional entity in the 2016 revision to the WHO classification [5]. This B-ALL subtype has a gene expression profile similar to Ph-positive ALL but lacking the canonical BCR-ABL1 fusion gene that arises from the reciprocal translocation between chromosomes 9 and 22 [25]. The BCR-ABL1 oncoprotein has a constitutively activated TK enzymatic activity which confers a proliferative and survival advantage by activating several downstream pathways, including Ras/MEK/ERK, PI3K/Akt/mTOR, and Janus kinase (JAK)/signal transducer and activator of transcription proteins (STAT) [26]. Likewise, Ph-like ALL harbors a kinase activated signaling that still results from a multitude of different genetic rearrangements and mutations.

Ph-like ALL was described almost 10 years ago by two independent studies that identified a subset of pediatric ALL characterized by a specific gene expression profile similar to that of Ph-positive ALL $[27,28]$.

Den Boer et al., employed a gene expression-based approach to classify the major subtypes of ALL, in order to improve prognostic classification of ALL in children, and hierarchical clustering revealed B-ALL cases that, although lacking the BCR-ABL1 fusion protein, clustered together with Ph-positive ALL [27]. This novel ALL subtype, called Ph-like or BCR-ABL1-like ALL, was characterized by a high frequency of deletions in genes involved in B-cell development (e.g., IKZF1) and by an unfavorable prognosis, with disease free survival rates comparable to that of pediatric patients with the Ph-positive ALL [27]. Mullighan et al., deeply characterized copy number alterations in high-risk ALL, and reported the strong association between deletions or mutations of IKZF1 and poor outcome [28]. In addition, by employing an independent gene expression signature, they defined IKZF1-mutated $B C R-A B L 1$-negative cases with a gene expression profile as similar to BCR-ABL1-positive ALL [28].

Ph-like cases lack single founding genomic alterations, but are defined by multiple genetic aberrations that converge on TK and cytokine receptor signaling pathways [29]. These alterations can be classified into discrete subgroups, based on the signaling pathway they affect. These include Cytokine Receptor Like Factor 2 (CRLF2) rearrangements (IGH-CRLF2 and P2RY8-CRLF2) or mutations (p.Phe232Cys), fusions involving ABL-class genes (ABL1, ABL2, CSF1R, LYN, PDGFRA, and PDGFRB), alterations activating JAK/STAT signaling (IL7R, SH2B3, JAK1, JAK3, TYK2, and IL2RB mutations/deletions, and JAK2, EPOR or TYK2 rearrangements), Ras signaling pathways (NRAS, KRAS, and PTPN11) and other less common fusions (FLT3, FGFR1, NTRK3 and PTK2B) $[23,24,30]$.

About half of pediatric Ph-like ALL show alterations in CRLF2 gene, a member of the type I cytokine receptor family [24,30]. CRLF2 is a receptor for thymic stromal lymphopoietin (TSLP) that forms a heterodimeric complex with interleukin 7 (IL7) receptor (IL7R) and is involved in controlling cell proliferation and development via STAT3, STAT5, and JAK2 pathways during normal B-cell development. In Ph-like ALL, rearrangements with the immunoglobulin heavy chain locus (IGH-CRLF2) and a focal interstitial deletion, joining CRLF2 to the adjacent P2RY8 gene (P2RY8-CRLF2), result in CRLF2 overexpression and increase CRLF2 protein expression [24,30]. In addition, less common point mutations lead to CRLF2 homodimerization and constitutive kinase signaling [31]. However, 
CRLF2 over-expression is not an independent poor prognostic indicator in children with B-ALL [32]. Aberrant CRLF2 expression very frequently co-occurs with JAK1/JAK2 activating mutations or other mutations deregulating JAK/STAT signaling (e.g., IL7R mutations) [24,30], and these genetic lesions collaborate to induce ligand-independent activation of downstream signal transduction pathways. Deregulation of JAK/STAT signaling may also be due to JAK2 or EPOR rearrangements, or to additional alterations activating other JAK/STAT signaling genes (IL7R, FLT3, SH2B3, JAK1, JAK3, $T Y K 2$, and $I L 2 R B)$, accounting for $8 \%, 4 \%$ and $12 \%$ of pediatric Ph-like ALL, respectively $[24,30]$.

The second major subgroup of Ph-like ALL includes ABL class fusions, involving ABL1, ABL2, CSF1R, and PDGFRB, identified in about $12-14 \%$ of pediatric Ph-like ALL, whereas mutations involving the Ras pathway were identified in about $6 \%$ of cases $[24,30]$.

Collectively, a deeper analysis of the genomic landscape of Ph-like ALL showed that only a minority of patients does not harbor kinase activating alterations, highlighting the potential of JAK and ABL inhibition in the treatment of these higher-risk patients.

Since kinase-activating alterations were identified in over 90\% of pediatric Ph-like ALL [24], and most of them converge on clinically actionable signaling, there is a great interest in identifying Ph-like patients, aiming to improve their outcome by using TK inhibitors (TKi) and JAK inhibitors. Different preclinical studies supported the evaluation of TKI Imatinib or Dasatinib in combination with chemotherapy [33] and several case reports corroborate the efficacy of TKIs in refractory Ph-like ALL patients with PDGFRB fusions [34-37]. For that reason, Dasatinib is currently tested in combination with chemotherapy to improve the cure rate of pediatric patients (NCT03117751; NCT01406756). Concerning Ph-like ALL with JAK/STAT pathway lesions, the addition of Ruxolitinib (a JAK inhibitor) to combination chemotherapy to treat pediatric patients is currently tested in three clinical trials (NCT03117751; NCT02723994; NCT02420717).

Actually, it is important to remind the remarkable progresses achieved in the treatment of Ph-positive ALL after the development of ABL TKi, whose introduction dramatically improved the prognosis, with disease-free survival in pediatric patients exceeding 70\% [3]. However, identification of Ph-like ALL is currently challenging, and appropriate assays are not yet available as ordinary diagnostic approaches [38].

\section{4. iAMP21 B-ALL}

Intrachromosomal amplification of chromosome 21 (iAMP21) B-ALL is characterized by amplification of a portion of chromosome 21 . It occurs in about $2 \%$ of children with B-ALL and it is associated with an intermediate prognosis [39]. This cytogenetic abnormality is caused by intrachromosomal amplification on chromosome 21, with the gain of more than two or three extra copies of RUNX1 with loss of subtelomeric region [39,40]. RB1 and EBF1 deletions, CRLF2 activating rearrangements, gain of the $\mathrm{X}$ chromosome and partial deletion of chromosome 7 have been frequently found in iAMP21 B-ALL [41]. Moreover, recurrent somatic mutations of the Ras/MEK/ERK pathway have been identified [42] and the MEK1/2 inhibitor Selumetinib showed strong cytotoxicity to leukemic iAMP21-positive cells, offering a possible targeted therapeutic strategy for iAMP21 B-ALL [42]. Of note, Selumetinib is currently undergoing clinical trials for the treatment of adult and pediatric ALL (NCT03705507).

\section{MEF2D-Rearranged B-ALL}

Myocyte enhancer factor 2D (MEF2D)-rearranged ALL arise in around 4\% of pediatric ALL and may be considered as a biologically distinct form of leukemia. MEF2D-rearranged ALL patients have a poor prognosis; thus, a novel therapeutic strategy should be considered for this B-ALL subtype. 
The MEF2D gene encodes a transcription factor involved in the muscular and neuronal differentiation that is regulated by histone deacetylases (HDAC) [43-45]. MEF2D plays a critical role in early B-cell differentiation, regulating the transition from the immature B-cell stage to the subsequent phases of B-cell development, through a Ras/MEK/ERK-dependent mechanism [46].

Several fusion partners in MEF2D rearrangements have been identified so far, including Bc19, CSF1R, DAZAP1, FOXJ2, HNRNPUL1, HNRNPH1, and SS18 $[47,48]$. All these rearrangements lead to expression of chimeric fusion oncoproteins, characterized by increased MEF2D transcriptional activity that causes hematopoietic cell transformation [47].

$\mathrm{Bcl}$, the most common fusion partner, is a co-transcriptional activator that forms a multiprotein complex required for transcription of $\mathrm{Wnt} / \beta$-catenin-dependent genes. The role of $\mathrm{Bcl} 9$ in cell growth, survival and development of leukemia is well established [49]. Notably, Wnt/ $\beta$-catenin pathway is involved in self-renewal of healthy stem cells [50], as well as of leukemic stem cells (LSCs) [51]. An aberrant increase in the levels of $\beta$-catenin exerts oncogenic effects via the activation of downstream gene expression programs. Therefore, inhibition of $\mathrm{Wnt} / \beta$-catenin pathway is a novel promising therapeutic strategy for hematological malignancies. Of note, PRI-724, a CBP/ $\beta$-catenin transcription inhibitor, has now entered early-phase clinical trials for hematological malignancies, where it displays a tolerable toxicity profile (NCT01606579, NCT02195440).

Even though Bc19 is involved in Wnt/ $\beta$-catenin signaling network, it is not yet clear if the MEF2D-Bc19 fusion protein directly interferes with Wnt/ $\beta$-catenin pathway [47]. Interestingly, the other MEF2D partner, SS18, is involved in Wnt/ $\beta$-catenin signaling pathway [52]. In synovial sarcoma, it has been reported that SS18 and $\beta$-catenin may both induce Wnt-dependent genes transcription, although they use different molecular complexes resulting in a synergistic effect [53]. Moreover, SS18 high levels lead to Wnt/ $\beta$-catenin axis activation in HEK293 cells [54].

Finally, expression of MEF2D-Bc19 fusion in a B-ALL cell line induces cell growth, resistance to dexamethasone and increase of HDAC9 expression [47,48,55].

A preclinical study shows that MEF2D-rearranged primary cells are sensitive to panobinostat, a HDAC inhibitor (HDACi), probably through the inhibition of HDAC9, which is overexpressed in MEF2D-rearranged B-ALL, offering a possible therapeutic option for MEF2D-rearranged ALL [47].

Several HDACi have already undergone clinical trials for ALL, including Panobinostat, alone (NCT00723203) or in combination with conventional chemotherapeutic drugs in childhood patients (NCT01321346, NCT02518750), Entinostat (NCT01383447), or Vorinostat, combined with Bortezomib for infants (NCT02553460) or children (NCT01312818).

\section{ZNF384-Rearranged B-ALL}

ZNF384-rearrangements are observed in 5\% of pediatric B-ALL patients and are related to an intermediate prognosis. The ZNF384 gene encodes a $\mathrm{C} 2 \mathrm{H} 2$ zinc finger transcription factor that regulates the promotors of different matrix metalloproteinases [56].

The ZNF384 rearrangement may involve several partners, including transcriptional regulators or chromatin modifiers, such as ARIDIB, BMP2K, CLTC, CREBBP, EWSR1, NIPBL, SMARCA2, SYNRG, TAF15, and TCF3 [57].

ZNF384-rearranged B-ALL show a characteristic immunophenotype, with low CD10 expression and expression of myeloid markers CD13 and/or CD33, while clinical features depend on the functional defect of the different fusion partner genes.

TCF3-ZNF384-rearranged B-ALL represents the most frequent fusion gene involving ZNF384 and is characterized by a poorer chemotherapeutic response and a higher frequency of relapse compared to the other ZNF384 rearrangements [58]. Recurrent mutations in RAS signaling pathway genes (NRAS, KRAS, PIK3CD, and PTPN11) have been identified in TCF3-ZNF384-rearranged B-ALL [59], and this may explain at least partly the aggressive clinical course of this B-ALL subtype.

In 2015, Ohara's group isolated a novel recurrent histone acetyltransferase p300 (EP300)-ZNF384 gene fusion, found in about $1.5 \%$ of pediatric B-ALL and showing clinical features significantly different 
from the other ZNF384-positive patients. For instance, EP300-ZNF384-positive patients have a more favorable prognosis [60]. EP300 acts on chromatin remodeling and has an onco-suppressor activity [61]. Moreover, the EP300-ZNF384 samples show an up-regulation of JAK/STAT pathway and reduced DNA repair capacity [62].

EP300- and CREBBP-ZNF384 rearranged B-ALL result in loss of histone lysine acetyltransferase activity, reduction of histone acetylation and increased sensitivity to $\mathrm{HDACi}$, opening the possibility to use these inhibitors for these specific B-ALL subtypes.

\section{DUX4-Rearranged B-ALL}

A recently discovered distinct B-ALL subtype is characterized by recurrent DUX4 rearrangements and a peculiar gene expression profile.

Genetic alterations of DUX4 account for about 4-7\% of B-ALL in pediatric cases and increase to more than $15 \%$ in adolescent and young adults (AYA) B-ALL [63-65].

The presence of DUX4-rearrangements has a favorable impact on prognosis and is associated with a longer disease-free survival, irrespective of the presence of IKZF1 alterations, that are well-known to confer poor prognosis in other B-ALL subtypes $[64,66]$.

The DUX4 gene is located in the subtelomeric region of chromosome $4 \mathrm{q}$ known as D4Z4. This region is highly polymorphic and, in normal genomes, it consists of repeated segments varying from 11 to more than 100, each containing a copy of the DUX4 gene. The DUX4 gene is normally exclusively expressed in germ cells during early stem cell development, but little is known about the function of the protein [67].

DUX4 rearrangements to either IGH or, less commonly, ERG genes are somatic events [63-65]. IGH-DUX4 and ERG-DUX4 fusions result from insertions of a partial copy of DUX4 into the IGH locus or into intron 3 of $E R G$, respectively, that relocate $D U X 4$ under the control of the partner gene enhancer, thus leading to aberrant overexpression of DUX4. Even though these fusions do not give rise to chimeric proteins, they result in a $3^{\prime}$ truncated DUX4 transcript, leading to a protein that retains both homeobox domains, consequently preserving its DNA-binding capacity [65].

In cell-based assays, DUX4 fusions exhibited oncogenic activity; by contrast, knockdown of the DUX4 fusion transcript suppressed cell proliferation. Furthermore, in vivo DUX4-IGH fusion showed leukemogenic potential in transplantation assay in mice and the pro-B cells expressing DUX4-IGH gave rise to pro-B cell leukemia [64].

The associated gene expression pattern is similar to those previously described in a subtype of B-ALL enriched for ERG deletions and associated with a favorable prognosis [68]. Consistently, the majority of DUX4-rearranged ALL harbor ERG focal deletions [63,65], but ERG deregulation occurs in all DUX4-rearranged ALL through multiple mechanisms, including expression of aberrant $E R G$ transcripts, intron retention and expression of ERGalt, an alternative transcript that utilizes a non-canonical first exon. In addition, DUX4 induces ERGalt expression, by binding to the alternative transcription initiation site of ERG in intron 6, that is the non-canonical first exon of ERGalt. In turn, ERGalt inhibits the function of wild-type ERG [65].

In DUX4-rearranged B-ALL, additional recurrent genomic alterations affect the lymphoid transcription factor genes IKZF1 and PAX5. Mutations were detected also in transcription factors and transcriptional regulators including $M Y C, M Y C B P 2, M G A$ and $Z E B 2$, in genes involved in activation of Ras signaling, cell cycle regulation, and epigenetic modifiers including KMT2D, SETD2, ARID2 and NCOR1 [63,65].

DUX4 could be a potential therapeutic target. Since aberrant expression of DUX4 was identified as a major factor in the etiology of facioscapulohumeral dystrophy (FSHD), several therapeutic approaches were developed to inhibit its expression in this context and could be potentially useful to treat DUX4-rearranged ALL. However, at present there are no clinical trials testing DUX4 inhibitors or preclinical evidence proving their efficacy in B-ALL harboring DUX4 rearrangements. In addition, 
the complexity of the genomic region where DUX4 is located makes difficult the identification of these rearrangements without high throughput screening.

\section{Pax5-Driven B-ALL}

Alterations of the B-lymphoid transcription factor gene PAX5 represent the most frequent somatic mutation in childhood B-ALL patients. In B-ALL, PAX5 can be altered by different somatic genomic abnormalities, such as deletions, gene fusions, and point mutations [69]. PAX5 alterations are initiating, subtype-defining events in B-ALL, interfering with the normal B-lymphoid development and interacting with activated kinase signaling $[47,70]$.

PAX5 is a transcription factor required for B-lineage development and maintenance [71]. It acts by activating the expression of B-lineage-specific genes, including CD79a, CD19, CD21, BLNK, CD72 or by inhibiting the transcription of other inappropriate genes, such as NOTCH1, PD1, and M-CSFR. Two different subtypes of B-ALL show PAX5 alterations: PAX5alt and PAX5 P80R.

\subsection{PAX5alt}

The first subtype PAX5alt, or "PAX5 altered", comprises all PAX5 rearrangements, sequence mutations and structural variants [47,72]. PAX5 rearrangements may occur with different partners, such as POM121, BRD1, DACH1, HIPK1 and JAK2 (PAX5-JAK2 rearrangement has been found in Ph-like ALL, leading to aberrant activation of JAK/STAT signaling pathway) and all these rearrangements are observed in approximately $11 \%$ of B-ALL childhood patients [73]. PAX5alt subtype is associated with an intermediate prognosis [47].

Further frequent alterations have been found in PAX5alt patients and involve different genes, including CDKN2A, IKZF1, ETV6 and LEF1, or lead to epigenetic modifications in KDM6A, KMT2A or ATRX [70].

Through induced PAX5 loss, Liu et al., reported that PAX5 deficiency contributes to leukemogenesis, by supporting B-ALL self-renewal and by blocking a differentiation program that can be re-engaged despite the presence of additional oncogenic lesions to B-ALL maintenance [74]. Importantly, PAX5 deficiency plays a fundamental role for both B-ALL pathogenesis and maintenance, through constitutively STAT5 activation [73-75].

It has been suggested that PAX5 activity needs a threshold under which it cannot induce the B-lineage differentiation program [71]. In this context, it would be important for B-ALL PAX5alt patients to develop therapeutic compounds aimed at restoring or mimicking full PAX5 activity.

Notably, PAX5 loss increases c-myc expression and proliferation in B-ALL, opening the possibility to consider c-myc as a novel, potentially highly effective target against childhood B-ALL overexpressing c-myc and harboring PAX5 rearrangements and mutations.

Indeed, recent findings reported that bromodomains (BRD) extra terminal (BET) inhibitors (BETi), which act inhibiting C-MYC transcription, are strongly cytotoxic in primary B-ALL cell lines and xenografts [76] and in pediatric primary B-ALL samples [77]. Moreover, it has been reported that PAX5 loss is accompanied by mutations in additional signaling pathways genes, including Ras and JAK/STAT [78], and BETi also act by inhibiting STAT5-dependent gene expression [79]. Clinical studies with Ras and JAK/STAT inhibitors in Pax5alt B-ALL patients are therefore warranted.

\subsection{PAX5 P80R}

The second PAX5-driven subtype is characterized by the presence of a unique PAX5 mutation (P80R) that leads to loss of PAX5 activity [80]. This mutation has been observed in around $2 \%$ of B-ALL childhood patients [81].

The outcome of PAX5 P80R-mutated patients is favorable. Interestingly, patients carrying this mutation are characterized by frequent aberrant activation of signaling pathways involved in cell growth, such as Ras, JAK/STAT, and PI3K/Akt/mTOR, demonstrating a close relationship between PAX5 activity and signaling pathways [70]. NRAS, PTPN11 and IL7R genes are most commonly 
mutated in the PAX5 P80R subtype. Moreover, PAX5 P80R patients frequently harbor deletion of $C D K N 2 A$ gene, enrichment of $M Y C$ and $E 2 F$ target genes and mutations in signal transduction factor genes, particularly in genes activated by mTOR and involved in Ras signaling pathway [47,80].

Recently, germline hypomorphic mutations in the PAX5 subtype have been related to B-ALL susceptibility, such as the recurrent germline PAX5 mutation (p.G183S), that has been identified in a familial ALL $[82,83]$.

\section{ETV6-RUNX1-Like B-ALL}

$t(12 ; 21)$ is the most common translocation in pediatric B-ALL, with a frequency of $25 \%$ [25], that involves ETV6 and RUNX1, two transcription factors both essential for normal hematopoiesis. Although ETV6-RUNX1 does not represent an independent predictor of prognosis, when age and white blood cell count at the time of diagnosis are taken into account in multivariate analysis, its presence is associated with a good prognosis, with event-free survival rates of approximately $90 \%$ [84].

In 2016, Lilljebjörn et al., described the gene fusion landscape of pediatric B-ALL [63]. Through RNA-sequencing and gene expression profiling, they were able to classify 191/195 (98\%) cases into distinct genetic subtypes. In particular, they identified in-frame gene fusions in the majority of cases $(65 \%)$, whereas the remaining cases were classified as high-hyperdiploid, hypodiploid and Ph-like. In addition, they defined a novel B-ALL subtype associated with ETV6-RUNX1-like gene-expression pattern in 3\% of the original cohort. The ETV6-RUNX1-like cases fall into B-other cases (defined as B-ALL without genetic aberrations at diagnosis, for which the leukemia driver events are still unknown), representing $14 \%$ of this B-ALL subgroup. ETV6-RUNX1-like cases harbored co-existing ETV6 and IKZF1 aberrations, including alternative in-frame ETV6 gene fusions (ETV6-PMEL, ETV6-BORCS5, ETV6-NID1), ETV6 deletions (both intragenic or whole-gene deletions), out-of-frame ETV6 fusions in combination with IKZF1 in-frame (reciprocal SETD5-IKZF1 and IKZF1-SETD5) or out-of-frame fusions, as well as IKZF1 whole-gene deletions, thus suggesting that combined ETV6 and IKZF1 lesions may activate similar transcriptional programs, as the ETV6-RUNX1 fusion protein. Of note, both IKZF1 and RUNX1 encode transcription factors important for B-cell maturation.

A further study reported the association of ETV6-RUNX1-like ALL with CD27pos/CD44 low-neg immunophenotype [85]. The $\mathrm{CD} 27^{\mathrm{pos}} / \mathrm{CD} 44^{\text {low-neg }}$ expression pattern was previously reported as distinct and exclusive of ETV6-RUNX1-positive ALL and these leukemic cells correspond to the physiological counterparts of less mature stage of B-cell precursors. In contrast, CD27 $7^{\text {neg }} / \mathrm{CD} 44^{\text {pos }}$ cells correspond to most of the ETV6-RUNX1-negative ALL and, in physiological conditions, appear later in B-cell precursor development [86]. Because a close genotype-phenotype correlation is exceptionally rare, Zaliova et al., deeply investigated several CD27 ${ }^{\text {os }} / C D 44^{\text {low-neg }}$ ETV6-RUNX1-negative B-other ALL cases [85]. Gene expression profiling revealed a significant biological similarity of these ETV6-RUNX1-negative B-other ALL cases to ETV6-RUNX1-positive ALL, since 5 out of 7 cases clustered within the ETV6-RUNX1-positive subtype and, therefore, were classified as ETV6-RUNX1-like ALL. Furthermore, single nucleotide polymorphism (SNP) array analysis, whole exome (WES) and whole transcriptome (RNAseq) sequencing defined their genomic background. All the five cases harbored ETV6 genetic aberration, including partial monoallelic deletions and in-frame ETV6-BORCS5 fusion. Co-occurring ETV6 alterations were also identified, including loss of ARPP21 (3/5), PAX5 (2/5), ATP10A $(2 / 5)$ and BTG1 (2/5) genes and IKZF1 aberrations (deletion, nonsense mutation, and gene fusion).

ETV6-RUNX1-like B-ALL is a clinically relevant pediatric B-ALL subtype with prognostic relevance, and its identification is essential to improve risk stratification of B-other ALL cases. The frequency of ETV6-RUNX1-like B-ALL reaches 5\% [87] and in a large-scale international study ETV6-RUNX1-like B-ALL, likewise ETV6-RUNX1-positive subtype, was identified only in pediatric cases and it was associated with low risk [81]. 


\section{NUTM1 Rearranged B-ALL}

NUT Midline Carcinoma Family Member 1 (NUTM1) fusion represents a rare recurrent childhood rearrangement, defining an infrequent B-ALL subgroup (1-2\%) with a favorable outcome that has been found exclusively in children [88]. NUTM1 acts as a chromatin modifier by recruiting EP300 to increase histone acetylation [89] and it is not normally expressed in leukemic lymphoblasts [88]. The NUTM1 rearrangement may involve different partners, such as ACIN1, BRD9, CUX1, IKZF1, SLC12A6, and ZNF618, all resulting in NUTM1 over-expression $[47,81]$. NUTM1 rearrangements characterize a rare and aggressive subtype of squamous cell carcinoma defined NUT carcinoma (NC), that predominantly affects teens and young adults [90]. In NC, NUTM1 recruits histone acetyltransferases and other transcriptional co-factors activating pro-proliferative and anti-differentiation genes, such as MYC [91].

It is well-established that BETi have strong antitumor activity in NC [92]. BETi are drugs that competitively block the binding of BET proteins (e.g., c-myc) to acetylated lysines of histones. Importantly, a BETi is currently undergoing clinical trials for the treatment of NC carcinoma (NCT01587703). Thus, the efficacy of BETi in NC treatment opens the possibility to extent the administration of these drugs to NUTM1 B-ALL patients to generate a unique therapeutic opportunity for this B-ALL subtype.

\section{Targetable Signaling Pathways in B-ALL}

The identification of novel B-ALL subtypes and their genomic anomalies provides a better therapeutic combination, with the aim to target several key survival pathways that will further ameliorate the therapeutic options, especially for refractory and relapsed pediatric patients, leading to spare to the younger patients the side effects elicited by conventional chemotherapeutic protocols (Figure 2, Tables 1 and 2).

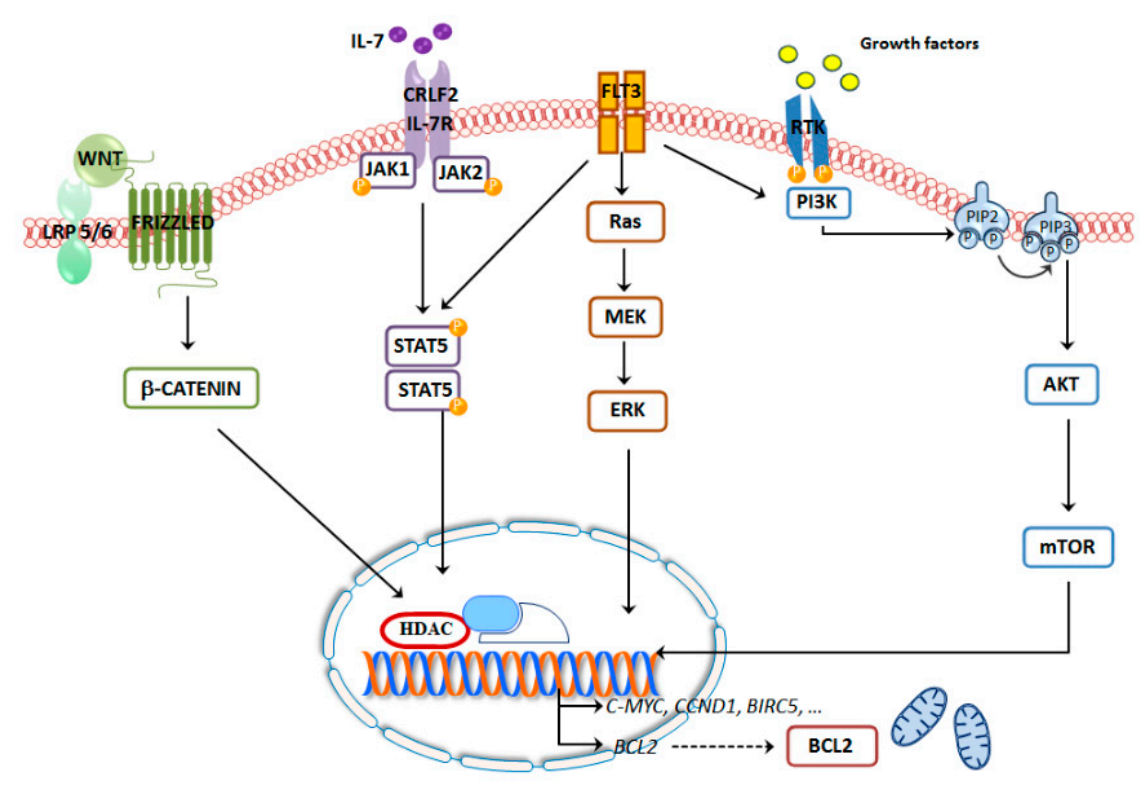

Figure 2. Most common signaling pathways involved in B-ALL. 
Table 1. Targetable pathways of childhood B-ALL subtypes.

\begin{tabular}{ccccc}
\hline B-ALL Subtype & Prognosis & Altered Signaling Pathways & Target & Ref \\
\hline MEF2D & Unfavorable/Intermediate & Ras/MEK/ERK, Wnt/ß-catenin & HDAC & {$[47]$} \\
ZNF384 & Intermediate & Ras, JAK/STAT & HDAC & {$[56]$} \\
DUX4 & Very Favorable & Ras & & {$[63]$} \\
Hypodiploidy & Unfavorable/Intermediate & Ras, PI3K/Akt/mTOR & Bcl2 & {$[6]$} \\
Hyperdiploidy & Very Favorable & Ras/MEK/ERK & MEK & {$[8]$} \\
Pax5 alt & Intermediate & c-myc & BET & {$[73]$} \\
Pax5 P80R & Favorable & Ras, c-myc, IL7 & & {$[80]$} \\
Ph-like & Unfavorable & JAK/STAT, ABL1, Ras, & mTOR, JAK & {$[25]$} \\
ETV6-RUNX1-like & FI3K/Akt/mTOR/IL7 & ABL1 & {$[25]$} \\
NUTM1 & Very Favorable & & BET & {$[88]$} \\
iAMP21 & Intermediate & c-myc & MEK & {$[42]$} \\
\hline
\end{tabular}

Table 2. Clinical trials activated for hematological malignancies and pediatric ALL involving the most important signaling pathways (clinicaltrials.gov).

\begin{tabular}{cccc}
\hline Drug & Target & Disease & Clinical Trials \\
\hline Everolimus & mTOR & Pediatric ALL & NCT01523994 \\
Selumetinib & MEK1/2 & Pediatric ALL & NCT03705507 \\
PRI-724 & B-catenin & Hematogical malignancies & NCT01606579 \\
& & & NCT02195440 \\
Venetoclax & Bcl2 & Pediatric ALL & NCT03504644 \\
Molibresib & BET proteins & Hematogical malignancies & NCT03236857 \\
OTX015 & BET proteins & Hematogical malignancies & NCT01943851 \\
Panobistat & HDAC & Pediatric ALL & NCT01321348 \\
Entinostat & HDAC & B-ALL & NCT02518750 \\
Vorinostat & HDAC & Pediatric ALL & NCT025834460 \\
& & & NCT01312818 \\
Ruxolinib & JAK/STAT & Pediatric ALL & NCT02723994 \\
& & & NCT02420717 \\
Dasatinib & \multirow{2}{*}{ ABL1 } & Pediatric Ph-like ALL & NCT03117751 \\
& & & NCT02420717 \\
& & & NCT01406756 \\
\hline
\end{tabular}

\subsection{Ras}

Activating mutations in Ras proteins are among the most common mutations in cancer. In B-ALL, the great majority of RAS mutations (98\%) occur in NRAS, KRAS, FLT3 and PTPN11 genes. All of them play important roles in regulating cellular processes involved in tumorigenesis, including cell growth, survival, differentiation, and cell cycle regulation [93].

Recently, it has been showed for the first time that mutations in RAS-related genes are significantly more frequent in childhood B-ALL patients, reaching $44 \%$ of cases [94,95].

RAS mutations have been found in several B-ALL subtypes, including TCF3-ZNF384-rearranged B-ALL [59], hypodiploid [6], high hyperdiploid [8], Pax5alt [78] and P80R [70], TCF3-HLF-rearranged B-ALL [96], Ph-like [24] and iAMP21 B-ALL [42].

Notably, RAS mutations involving NRAS, KRAS, FLT3 and PTPN11 genes confer a bad prognosis [94,97-99], probably due to chemo-resistance mechanisms. Indeed, it has been previously reported that RAS mutations are related to chemo-resistance mechanisms [100]. RAS-mutated cells are resistant to Prednisolone, as well as to Vincristine and, more importantly, GC chemo-resistance can be eradicated by Ras pathway inhibition [101]. Ras proteins act mainly through two different signaling cascades, the Ras/MEK/ERK and the PI3K/Akt/mTOR pathways [93], that are often aberrantly activated in B-ALL. 


\subsection{PI3K/Akt/mTOR Signaling}

PI3K/Akt/mTOR signaling network represents a critical signal transductioncascadeinvolved in several cellular functions, including mRNA translation, proliferation, survival, metabolism, and autophagy [102].

Dysregulation of PI3K/Akt/mTOR pathway is frequently reported in B-ALL [103] and correlates with worse prognosis and chemo-resistance in pediatric B-ALL patients [15].

Several inhibitors of the PI3K/Akt/mTOR axis were developed and tested in ALL patients [104]; nevertheless, only few of those drugs have been evaluated in childhood ALL patients [105].

However, drugs targeting PI3K/Akt/mTOR pathway showed promising results in preclinical models of B-ALL, through the direct inhibition of tumor cell growth and by reversal of GC resistance, although with a limited success when used as single anticancer agents [106]. On the contrary, these drugs demonstrated significant cytotoxic effects when combined with other chemotherapeutic agents, including Dexamethasone, Doxorubicin, L-Asparaginase, Methotrexate and Etoposide, and several progressed to clinical trials [106]. Encouraging results have been shown for relapsed childhood B-ALL [107], as also reported by a recent phase I clinical trial combining Everolimus (an allosteric mTOR inhibitor) with conventional chemotherapeutic drugs (NCT01523977).

The promising results obtained by the treatment of resistant and relapsed patients can be explained by the fact that up-regulation of PI3K/Akt/mTOR pathway is involved in chemo-resistance mechanisms, and specific inhibitors were able to overcome the resistance mechanisms, first of all by inhibiting the aberrant activation of the Ras/MEK/ERK pathway or the RTK overexpression [108].

The presence of CRLF2 rearrangements, the most common alteration in Ph-like ALL, associates with aberrant JAK/STAT and PI3K/Akt/mTOR signaling pathways. In vitro studies demonstrated the interconnection between these two pathways, since stimulation with TSLP, which is the CRLF2 ligand, induced phosphorylation of both JAK/STAT and PI3K/Akt/mTOR pathway components, while treatment with the JAK inhibitor Ruxolitinib inhibited the activation of STAT5, ERK1/2 (downstream JAK/STAT signaling), Akt, S6RP, 4EBP1, and eIF4E (downstream PI3K/Akt/mTOR signaling), in both cell lines and primary samples from ALL patients [109]. Therefore, several studies investigated the therapeutic relevance of JAK/STAT and PI3K/Akt/mTOR inhibition. The mTOR inhibitor Rapamycin was evaluated in NSG xenograft models of specific subtypes of primary human B-ALL, demonstrating higher efficacy in Ph-like ALL than any other B-ALL subset, but particularly in B-ALL with altered CRLF2 and JAK/STAT signaling, in which it significantly prolonged patients' survival [110]. Moreover, the combination of JAK2 and mTOR inhibitors produced robust anti-leukemic effects in Ph-like cell lines in vitro and in PDX cells cultured ex vivo, as well as in in vivo Ph-like B-ALL PDX models [111]. Therefore, these findings confirm that PI3K/Akt/mTOR pathway is a relevant target, at least in some cases of Ph-like ALL. Despite the therapeutic potential of mTOR inhibition in these subtypes, that might have relevant clinical implications, it is essential to identify which subsets of B-ALL are more likely to respond, in order to successfully test mTOR inhibitors in future clinical trials.

\subsection{Ras/MEK/ERK Signaling}

Constitutive activation of Ras/MEK/ERK signaling pathway is a frequent event in leukemic cells and may be caused by mutations of RAS genes. The Ras/MEK/ERK network plays a pivotal role in mediating the oncogenic effects of Ras, suggesting the potential efficacy of targeting this pathway in RAS-mutated cancers [112].

Among the Ras/MEK/ERK inhibitors, Trametinib, a highly specific and potent MEK1/2 inhibitor, is currently investigated in B-ALL. Interestingly, B-ALL RAS-mutant cells are sensitive to Trametinib, that in turn can re-sensitize resistant cells to Prednisolone [101]. Moreover, Trametinib and Prednisolone showed synergistic effects in pediatric relapsed B-ALL patients [95]. It follows that the relationship between RAS mutations and GC resistance may offer a novel promising alternative therapeutic strategy for childhood B-ALL relapsed patients $[101,113,114]$. 


\subsection{Wnt/3-Catenin Signaling Pathway}

Canonical Wnt/ $\beta$-catenin pathway represents a crucial signaling axis involved in several cellular processes, including embryonic development, cell growth, wound healing, differentiation, apoptosis and migration [49]. This network acts through $\beta$-catenin that, translocating to the nucleus, activates several downstream target genes, such as $C-M Y C, C C N D 1$, and BIRC5 [115].

$\mathrm{Wnt} / \beta$-catenin axis regulates hematopoiesis, through hematopoietic stem cells (HSCs) maintenance and self-renewal [116]. Aberrant activation of this signaling cascade is therefore associated to HSCs uncontrolled self-renewal, possibly generating LSCs and leading to hematologic neoplastic disorders [51]. Importantly, $\beta$-catenin inhibition blocks the self-renewal of drug-resistant LSCs, pushing these cells towards symmetric differentiation, without interfering with normal HSCs asymmetric differentiation $[117,118]$.

The involvement of $\mathrm{Wnt} / \beta$-catenin pathway in B-ALL development has been firstly showed by Khan et al., that reported that activation of Wnt proteins increases proliferation of B-ALL cell lines [119]. Then, Petropoulos et al., showed in mice that overexpression of a constitutive active Lymphoid Enhancer Binding Factor (LEF) 1 mutant is sufficient to develop B-ALL [120], thus identifying LEF1 as a new potential oncogene. Moreover, given that overexpressed LEF1 has been found in $25 \%$ of all B-ALL patients, it could represent an independent adverse prognostic factor [121].

In B-ALL, constitutive active Wnt/ $\beta$-catenin pathway supports LSCs survival, together with bone marrow stromal cells [122], and in pediatric B-ALL is associated with drug-resistance [123,124]. Inhibition of $\mathrm{Wnt} / \beta$-catenin pathway may therefore overcome drug resistance, by sensitizing B-ALL cells to Cytarabine treatment both in vitro and in vivo [122].

The potential of combining Wnt/ $\beta$-catenin inhibitors with classical chemotherapy in B-ALL has been studied using ICG-001, a CBP/ $\beta$-catenin transcription inhibitor. ICG-001 induced the reduction of self-renewal capacity of B-ALL cells, through downregulation of survivin (the product of BIRC5 gene), thus overcoming drug-resistance in primary leukemia cells [124].

Moreover, recent findings reported that down-regulation of the $\beta$-catenin-dependent BIRC5 gene induces in vitro chemo-sensitivity. Therefore, a phase I study combining the survivin mRNA antagonist EZN-3042 with re-induction chemotherapeutic drugs has been developed for pediatric relapsed B-ALL patients (NCT01186328) [125].

$\mathrm{Wnt} / \beta$-catenin pathway dysregulation has been reported in different B-ALL subtypes, such as TFC3/PBX1 B-ALL, where Wnt16b is aberrantly activated by the expression of the E2A-Pbx1 fusion protein to induce leukemia $[126,127]$. Mazieres et al., confirmed that Wnt16b, $\beta$-catenin, Dvl2 and TCF4 are upregulated in TFC3/PBX1-positive cells and, more importantly, inhibition of Wnt16b leads to apoptosis [128].

Wnt/ $\beta$-catenin pathway is also dysregulated in Ph-like B-ALL, where the hyper-activation of this signaling cascade may be triggered by epigenetic alterations, such as hyper-methylation of promoters of the Wnt/ß-catenin antagonists SFRP, WIF1, and Dkk3 [129].

Finally, a crosstalk and correlation between up-regulation of Wnt/ $\beta$-catenin and Ras/MEK/ERK signaling pathways has been demonstrated in different cancers, including relapsed childhood B-ALL $[130,131]$, and it should require further preclinical studies [132].

\section{5. $\mathrm{Bcl} 2$}

The anti-apoptotic Bcl2 family proteins are overexpressed in many hematological malignancies, including B-ALL, where it has been found in more than $66 \%$ patients compared to healthy donors [133]. Indeed, in B-ALL, the balance of Bcl2 family proteins is often disrupted, pushing leukemic cells toward survival, and promoting leukemogenesis. That is why therapies targeting this anti-apoptotic regulator are considered as an attractive strategy for leukemia treatment.

A dual inhibitor of Bcl2 and Bcl-XL, named Navitoclax (ABT-263), resulted to be cytotoxic in Bcl2-dependent neoplasia, but it induced excessive cell toxicity during clinical trials, resulting in thrombocytopenia, and thus limiting its clinical application [134]. 
ABT-737, another Bcl2 inhibitor that neutralizes also Bcl-X, showed potent anti-leukemic activity in pre-clinical models, but its therapeutic use was limited because of lack of oral bioavailability and the induction of a strong decrease of circulating platelets, as reported for Navitoclax, so that these inhibitors never entered clinical phase III trials [135].

On the contrary, the highly selective Bcl2 inhibitor Venetoclax presented remarkable cytotoxic effects with significant reduced toxicity in comparison to dual Bcl2/Bcl-X inhibitors [136] in haematological malignancies, including acute myeloid leukemia (AML) $[137,138]$ and non-Hodgkin lymphoma (NHL) [139]. In line with these data, studies of MLL-ALL cells in vitro [140] and in vivo [138] confirmed the anti-leukemic activity of Venetoclax as monotherapy for the treatment of hematological malignancies. Moreover, this Bcl2 inhibitor showed strong cytotoxic effects in B-ALL cell lines and in pediatric B-ALL PDX models [96,141].

Given its safe profile, Venetoclax has recently been approved by FDA for CLL patients with the $17 p$ deletion [142]. Importantly, it also entered in a phase II clinical trials as monotherapy in patients with refractory and relapsed AML [143] and T-ALL [144].

Two clinical trials are analyzing the efficacy of Venetoclax in ALL. Firstly, safety and preliminary efficacy of Venetoclax combined with chemotherapy is being evaluated in a phase I clinical trial for pediatric ALL patients (NCT03236857) [145]. Another phase I trial will study the safety and pharmacokinetics of Venetoclax, Navitoclax, and chemotherapy in relapsed ALL (NCT03181126).

Recently, it has been reported that targeting $\mathrm{Bcl} 2$ is not effective as monotherapy for the treatment of childhood leukemia, but it becomes effective when associated with other drugs, such as inhibitors of survival pathways, thus allowing to induce apoptosis and to reduce side effects. Indeed, the anti-leukemic activity of Venetoclax treatment in B-ALL xenografts is weak, but it significantly increases when combined with Vincristine and Dexamethasone [141].

Given that $\mathrm{Bcl} 2$ activation could be the result of the dysregulation of activated signaling pathways, combined treatments with $\mathrm{Bcl} 2$ inhibitors and drugs targeting specific signaling pathways have been tested. For instance, targeting Bcl2 and PI3K/Akt/mTOR resulted in high cytotoxicity in vitro [107]. Moreover, combined treatment exerted synergistic growth-inhibitory effects and induced apoptosis in B-ALL cell lines and primary cells obtained from patients with resistant ALL patients [146]. The synergistic anti-leukemic effects of $\mathrm{Bcl} 2$ and PI3K/Akt/mTOR inhibitors may be explained by the fact that $\mathrm{Bcl} 2$ inhibitors may act by inducing apoptosis after $\mathrm{mTOR}$ inhibition, thus regulating both anti-apoptotic proteins, such as BCL-XL, and pro-apoptotic proteins, such as BAD or PUMA, as well as activators (BIM) or effectors (BAX) [107].

Further preclinical research supported these findings, highlighting that co-administration of PI3K/Akt/mTOR inhibitors and Venetoclax is synergistic in AML cells and in mice [147].

Promising results have been reported in TCF3-PBX1 B-ALL [127] and in hypodiploid B-ALL [6,11], suggesting that $\mathrm{Bcl} 2$ inhibition could be a encouraging strategy also for the treatment of these B-ALL subtypes. In conclusion, all preclinical data on Bcl2 inhibition in ALL confirmed the therapeutic potential of $\mathrm{Bcl} 2$ inhibition for B-ALL patients. Moreover, the FDA approval of Venetoclax for the treatment of CLL encourages its application also for pediatric B-ALL.

\subsection{BET Proteins}

The BET proteins are epigenetic readers that interact with acetylated histones and play important roles in proliferation and cell-cycle regulation [148]. In particular, they act as scaffolds for the activation of transcription factors and chromatin organizers required for the transcription of several pro-survival and anti-apoptotic genes, such as MYC and BCL2. Dysregulation of BET proteins is linked to the development of different diseases, including cancer [148]. That is why inhibition of the BET-histone interaction has recently gained increasing interest for the treatment of cancers characterized by altered histone acetylation and altered gene transcription, such as c-myc-dependent hematological malignancies and hematological malignancies with epigenetic alterations [149]. 
Several novel BETi have been developed by industrial and academic research groups, providing a novel pharmacological option for the treatment of cancer [150].

BETi showed an encouraging therapeutic potential in leukemia preclinical models, both as single agents and combined to other drugs. For instance, BETi showed cytotoxic effects in different hematological malignancies, including AML, lymphoma and ALL [76,151]. A strong anti-leukemic activity has also been reported in MLL-fusion leukemia, through the down-regulation of fundamental pro-survival genes, such as $B C L 2, C D K 6$ and MYC [152].

In B-ALL, BET inhibition causes strong cytotoxic effects, down-regulates the expression of the oncogenes c-myc and IL7R and leads to apoptosis to B-ALL cell lines and primary patient-derived cells $[76,77]$. Moreover, BETi treatment of B-ALL PDX mouse models decreased the tumor burden and increased overall survival.

In addition, c-myc inhibition reduced LSCs in mice, confirming the involvement of c-myc in LSCs maintenance in ALL $[153,154]$. Interestingly, BETi deplete LSCs, acting through inhibition of c-myc expression. Several BETi are currently being evaluated in clinical trials for the treatment of hematological malignancies, including ALL, with promising responses (NCT02158858, NCT01943851, NCT01713582), [149,155].

Recently, possible combination of BETi with targeting pathways drugs have been evaluated, especially to overcome BETi resistance. Wnt $/ \beta$-catenin signaling was shown as a driver of BETi resistance, restoring c-myc expression in AML. To confirm this, it has been showed that combined treatment synergizes in resistant AML cells [156]. Another study, using MLL-AF9-transduced progenitor cells, established that BETi-resistant cells displayed marked up-regulation of the Wnt/ $\beta$-catenin pathway, both in vitro and in vivo [157].

Another possible synergism using BETi for the treatment of B-ALL is through the down-regulation of Aurora kinase (Ak) B [158]. AkB is involved in centrosome function, mitotic spindle assembly and cytokinesis. Its overexpression is often reported in different cancers, where it correlates with higher malignancy, higher proliferation, and worse outcome [159]. In B-ALL, AkB is aberrantly activated by c-myc and is often overexpressed [158]. In addition, in mice xenografted with primary B-ALL cells, BETi treatment caused a strong inhibition of AkB [158].

Finally, BETi also act by inhibiting STAT5-dependent transcription of pro-apoptotic genes, through synergistic effects with TKi in leukemic cells [79], and inhibiting NF- $\mathrm{KB}$ pathway in drug-resistant leukemia [160]. All these preclinical evidence suggests that BETi may have clinical implications in B-ALL subtypes characterized by aberrant oncogenic transcription driven by c-myc, including NUTM1 and PAX5 mutations.

\section{7. $H D A C$}

HDACs regulate chromatin structure through the removal of acetyl residues of core histones, modulating gene expression [161]. In humans, there are 11 classical HDAC isoforms, grouped into four classes. Altered expression and mutations of genes that encode HDACs play a critical role in leukemogenesis. Therefore, HDACs represent promising therapeutic targets for leukemia treatment [161]. HDAC inhibitors (HDACi) have been approved for the treatment of cutaneous T-cell lymphoma and Panobinostat, a selective HDACi, received FDA-approval in 2015 for the treatment of multiple myeloma patients [162].

HDACi activity has been also tested in preclinical models of B-ALL, demonstrating strong pro-apoptotic effects [163]. Recently, selective HDACi (HDAC1 and HDAC2 inhibitors) have been tested in a panel of B-ALL cells, including pediatric B-ALL cells, and in xenografted human leukemia patient samples, showing promising results [164]. Selective inhibitors showed a comparable sensitivity, compared to non-selective HDACi, but they inhibited leukemic growth and activated apoptosis both in vitro and in vivo, allowing to lower the accumulation of dsDNA lesions frequently associated to non-specific HDACi. The strong cytotoxic effects of selective HDACi appears to be more marked in 
B-ALL, as the activity of these inhibitors is reduced in other B-derived malignancies [164]. Moreover, selective HDACi that avoid inhibition of HDAC3 seem to show clinical benefits [165].

Selective HDACi are already approved for a lymphoid malignancy, cutaneous T-cell lymphoma and are currently undergoing clinical investigation for ALL (NCT01132573, NCT00462605, NCT01321346).

\subsection{JAK/STAT}

As mentioned above, Ph-like ALL is characterized by a range of genomic alterations that converge on a limited number of signaling pathways, more frequently the JAK/STAT. Besides activating alterations, including mutations, deletions and gene rearrangements that affect IL7R, SH2B3, JAK1, $J A K 2$, JAK3, TYK2, IL2RB, EPOR or TYK2, also CRLF2-overexpressing ALL show aberrancies on the JAK/STAT pathway [109].

Preclinical in vitro studies demonstrated the ability of several fusion transcripts, for instance PAX5-JAK2, to confer cytokine-independent proliferation in mouse IL-dependent Ba/F3 cells and in IL7-dependent $\mathrm{Arf}^{-/-}$pre-B cells expressing a dominant negative isoform of Ikaros [24]. Of note, such cellular models, harboring PAX5-JAK2, as well as human leukemic cells harboring ATF7IP-JAK2 or IGH-EPOR, were sensitive to Ruxolitinib, a selective JAK1/2 inhibitor [24]. The in vivo efficacy of Ruxolitinib treatment has also been reported in JAK2-mutated/CRLF2-rearranged ALL xenografts [110]. Further preclinical in vivo investigations confirmed that Ruxolitinib is the most potent agent against the majority of JAK/STAT activating alterations, including the JAK-family fusions ATF7IP-JAK2, PAX5-JAK2 (apart from those involving TYK2), and the following mutations: IL7R p.IsoLeu241-242ThrCys, JAK1 p.Leu782Phe, JAK3 p.Val670Ala. In addition, the cytostatic effects of Ruxolitinib monotherapy were significantly enhanced to the addition of Dexamethasone, supporting the combination of multiple agents to eradicate leukemia [166]. Recently, four different rearrangements of EPOR gene were exclusively identified in Ph-like ALL [66]. These rearrangements juxtapose EPOR to enhancer regions in immunoglobulin and immunoglobulin-like genes, resulting in deregulated EPOR expression and promoting leukemogenic potential in vivo. Human leukemic cells with EPOR rearrangements enhanced JAK/STAT signaling and were sensitive to JAK/STAT inhibition. More importantly, in human xenografts, the JAK1/2 inhibitor Ruxolitinib exhibited potent synergism with conventional chemotherapeutic agents, including Dexamethasone, Vincristine, and Daunorubicin, thus offering an alternative therapy for this subset of Ph-like ALL.

Collectively, these studies provided the rationale for testing JAK inhibitor-based therapies in the clinics. Indeed, current several phase I-II clinical trials are now testing the efficacy of Ruxolitinib in combination with chemotherapy in pediatric patients with activation of JAK/STAT signaling, including de novo high-risk CRLF2-rearranged and/or JAK pathway-mutant ALL or Ph-like ALL (NCT02723994, NCT02420717, NCT03117751).

\subsection{ABL1 Kinase}

The second largest group of mutations in Ph-like ALL comprises ABL-class fusions (ABL1, ABL2, CSF1R, PDGFRB), that are predicted to respond to ABL1 inhibitors. The efficacy of such TKi has been evaluated in preclinical in vitro and in vivo models, and the ABL fusion genes RCSD1-ABL1, RSCD1-ABL2, SSBP2-CSF1R and ETV6-ABL1 were sensitive to a number of ABL1 inhibitors, including Imatinib, Dasatinib, Nilotinib and Ponatinib [24,166,167]. In addition, a multitude of reports involving pediatric patients indicate the benefit of an early introduction of ABL1 inhibition following the identification of ABL-class fusions as well as the application of TKi monotherapy to eradicate MRD [34-37,167]. Accordingly, several phase I-II clinical trials are testing dasatinib in combination with chemotherapy in patients with Ph-like ALL with ABL1-class fusion (NCT03117751, NCT02420717). 


\section{Conclusions}

B-ALL is the most prevalent cancer in childhood. Despite considerable improvements in overall survival, a proportion of pediatric B-ALL has still unsatisfactory outcomes with the current treatments.

The recent sequencing-based studies greatly improved the classification of childhood B-ALL, enabling the identification of novel subtypes characterized by druggable genomic anomalies. Since the genetic background impact on initiation, progression and outcome of this disease, these novel findings provide a better understanding of the pathobiology of B-ALL. In addition, these genetic abnormalities are clinically relevant for risk stratification, treatment choice and prognosis.

Although the outcome of several new B-ALL subtypes remains poor, targeted therapeutic strategies may potentially show a great impact on B-ALL prognosis, especially for subtypes that actually lack efficient therapeutic protocols.

Dysregulated signaling pathways are often interconnected in B-ALL, giving the opportunity to combine targeted compounds to enhance treatment efficacy and ultimately eradicate leukemia cells. In light of this, targeted therapy offers an unrivalled chance to simultaneously block multiple signaling while changing the course of cancer.

We expect in the next future great improvements in diagnostic tests, in order to support the routine identification of the novel molecular alterations that defines the new B-ALL subtypes, as well as continued investigations aiming at find new druggable targets that may enhance anti-leukemic efficacy while decreasing side effects. In conclusion, the recent efforts in basic, translational and clinical research might hopefully render B-ALL a curable disease.

Author Contributions: All of the authors contributed to the writing and editing of the article. All authors have read and agreed to the published version of the manuscript.

Funding: This research was funded by Fondazione Cassa di Risparmio di Bologna grant (to S.R.)

Acknowledgments: The authors thank Aurelio Valmori for the technical assistance.

Conflicts of Interest: The authors declare no conflict of interest.

\section{References}

1. Siegel, R.; Naishadham, D.; Jemal, A. Cancer statistics, 2013. Cancer J. Clin. 2013, 63, 11-30. [CrossRef] [PubMed]

2. Vadillo, E.; Dorantes-Acosta, E.; Pelayo, R.; Schnoor, M. T cell acute lymphoblastic leukemia (T-ALL): New insights into the cellular origins and infiltration mechanisms common and unique among hematologic malignancies. Blood Rev. 2018, 32, 36-51. [CrossRef] [PubMed]

3. Pui, C.H.; Yang, J.J.; Hunger, S.P.; Pieters, R.; Schrappe, M.; Biondi, A.; Vora, A.; Baruchel, A.; Silverman, L.B.; Schmiegelow, K.; et al. Childhood Acute Lymphoblastic Leukemia: Progress Through Collaboration. J. Clin. Oncol. 2015, 33, 2938-2948. [CrossRef] [PubMed]

4. Pui, C.H. Genomic and pharmacogenetic studies of childhood acute lymphoblastic leukemia. Front. Med. 2015, 9, 1-9. [CrossRef] [PubMed]

5. Arber, D.A.; Orazi, A.; Hasserjian, R.; Thiele, J.; Borowitz, M.J.; Le Beau, M.M.; Bloomfield, C.D.; Cazzola, M.; Vardiman, J.W. The 2016 revision to the World Health Organization classification of myeloid neoplasms and acute leukemia. Blood 2016, 127, 2391-2405. [CrossRef] [PubMed]

6. Holmfeldt, L.; Wei, L.; Diaz-Flores, E.; Walsh, M.; Zhang, J.; Ding, L.; Payne-Turner, D.; Churchman, M.; Andersson, A.; Chen, S.C.; et al. The genomic landscape of hypodiploid acute lymphoblastic leukemia. Nat. Genet. 2013, 45, 242-252. [CrossRef]

7. Forestier, E.; Johansson, B.; Borgstrom, G.; Kerndrup, G.; Johansson, J.; Heim, S. Cytogenetic findings in a population-based series of 787 childhood acute lymphoblastic leukemias from the Nordic countries. The NOPHO Leukemia Cytogenetic Study Group. Eur. J. Haematol 2000, 64, 194-200. [CrossRef]

8. Paulsson, K.; Lilljebjorn, H.; Biloglav, A.; Olsson, L.; Rissler, M.; Castor, A.; Barbany, G.; Fogelstrand, L.; Nordgren, A.; Sjogren, H.; et al. The genomic landscape of high hyperdiploid childhood acute lymphoblastic leukemia. Nat. Genet. 2015, 47, 672-676. [CrossRef] 
9. Mullighan, C.G.; Jeha, S.; Pei, D.; Payne-Turner, D.; Coustan-Smith, E.; Roberts, K.G.; Waanders, E.; Choi, J.K.; Ma, X.; Raimondi, S.C.; et al. Outcome of children with hypodiploid ALL treated with risk-directed therapy based on MRD levels. Blood 2015, 126, 2896-2899. [CrossRef]

10. Qian, M.; Cao, X.; Devidas, M.; Yang, W.; Cheng, C.; Dai, Y.; Carroll, A.; Heerema, N.A.; Zhang, H.; Moriyama, T.; et al. TP53 Germline Variations Influence the Predisposition and Prognosis of B-Cell Acute Lymphoblastic Leukemia in Children. J. Clin. Oncol. 2018, 36, 591-599. [CrossRef]

11. Diaz-Flores, E.; Comeaux, E.Q.; Kim, K.L.; Melnik, E.; Beckman, K.; Davis, K.L.; Wu, K.; Akutagawa, J.; Bridges, O.; Marino, R.; et al. Bcl-2 Is a Therapeutic Target for Hypodiploid B-Lineage Acute Lymphoblastic Leukemia. Cancer Res. 2019, 79, 2339-2351. [CrossRef] [PubMed]

12. Roberts, A.W.; Davids, M.S.; Seymour, J.F. New Agents to Treat Chronic Lymphocytic Leukemia. N. Engl. J. Med. 2016, 374, 2186-2187. [CrossRef] [PubMed]

13. Stilgenbauer, S.; Eichhorst, B.; Schetelig, J.; Hillmen, P.; Seymour, J.F.; Coutre, S.; Jurczak, W.; Mulligan, S.P.; Schuh, A.; Assouline, S.; et al. Venetoclax for Patients with Chronic Lymphocytic Leukemia With 17p Deletion: Results From the Full Population of a Phase II Pivotal Trial. J. Clin. Oncol. 2018, 36, 1973-1980. [CrossRef] [PubMed]

14. Khwaja, A. PI3K as a target for therapy in haematological malignancies. Curr. Top. Microbiol. Immunol. 2010, 347, 169-188. [CrossRef] [PubMed]

15. Morishita, N.; Tsukahara, H.; Chayama, K.; Ishida, T.; Washio, K.; Miyamura, T.; Yamashita, N.; Oda, M.; Morishima, T. Activation of Akt is associated with poor prognosis and chemotherapeutic resistance in pediatric B-precursor acute lymphoblastic leukemia. Pediatr. Blood Cancer 2012, 59, 83-89. [CrossRef]

16. Evangelisti, C.; Cappellini, A.; Oliveira, M.; Fragoso, R.; Barata, J.T.; Bertaina, A.; Locatelli, F.; Simioni, C.; Neri, L.M.; Chiarini, F.; et al. Phosphatidylinositol 3-kinase inhibition potentiates glucocorticoid response in B-cell acute lymphoblastic leukemia. J. Cell Physiol. 2018, 233, 1796-1811. [CrossRef]

17. Adam, E.; Kim, H.N.; Gang, E.J.; Schnair, C.; Lee, S.; Khazal, S.; Kosoyan, O.; Konopleva, M.; Parekh, C.; Bhojwani, D.; et al. The PI3Kdelta Inhibitor Idelalisib Inhibits Homing in an in Vitro and in Vivo Model of B ALL. Cancers 2017, 9, 121. [CrossRef]

18. Yao, H.; Price, T.; Olivere, L.; Warner, M.; Tannheimer, S.; Sipkins, D.A. PI3K delta inhibition suppresses central nervous system involvement of acute lymphoblastic leukemia. Blood 2016, 128, 282. [CrossRef]

19. Wiemels, J.L.; de Smith, A.J.; Xiao, J.; Lee, S.T.; Muench, M.O.; Fomin, M.E.; Zhou, M.; Hansen, H.M.; Termuhlen, A.; Metayer, C.; et al. A functional polymorphism in the CEBPE gene promoter influences acute lymphoblastic leukemia risk through interaction with the hematopoietic transcription factor Ikaros. Leukemia 2016, 30, 1194-1197. [CrossRef]

20. Walsh, K.M.; de Smith, A.J.; Chokkalingam, A.P.; Metayer, C.; Dahl, G.V.; Hsu, L.I.; Barcellos, L.F.; Wiemels, J.L.; Buffler, P.A. Novel childhood ALL susceptibility locus BMI1-PIP4K2A is specifically associated with the hyperdiploid subtype. Blood 2013, 121, 4808-4809. [CrossRef]

21. de Smith, A.J.; Lavoie, G.; Walsh, K.M.; Aujla, S.; Evans, E.; Hansen, H.M.; Smirnov, I.; Kang, A.Y.; Zenker, M.; Ceremsak, J.J.; et al. Predisposing germline mutations in high hyperdiploid acute lymphoblastic leukemia in children. Genes Chromosomes Cancer 2019, 58, 723-730. [CrossRef] [PubMed]

22. Wohrle, F.U.; Daly, R.J.; Brummer, T. Function, regulation and pathological roles of the Gab/DOS docking proteins. Cell Commun. Signal. 2009, 7, 22. [CrossRef] [PubMed]

23. Roberts, K.G.; Gu, Z.; Payne-Turner, D.; McCastlain, K.; Harvey, R.C.; Chen, I.M.; Pei, D.; Iacobucci, I.; Valentine, M.; Pounds, S.B.; et al. High Frequency and Poor Outcome of Philadelphia Chromosome-Like Acute Lymphoblastic Leukemia in Adults. J. Clin. Oncol. 2017, 35, 394-401. [CrossRef] [PubMed]

24. Roberts, K.G.; Li, Y.; Payne-Turner, D.; Harvey, R.C.; Yang, Y.L.; Pei, D.; McCastlain, K.; Ding, L.; Lu, C.; Song, G.; et al. Targetable kinase-activating lesions in Ph-like acute lymphoblastic leukemia. N. Engl. J. Med. 2014, 371, 1005-1015. [CrossRef] [PubMed]

25. Pui, C.H.; Carroll, W.L.; Meshinchi, S.; Arceci, R.J. Biology, risk stratification, and therapy of pediatric acute leukemias: An update. J. Clin. Oncol. 2011, 29, 551-565. [CrossRef]

26. Steelman, L.S.; Pohnert, S.C.; Shelton, J.G.; Franklin, R.A.; Bertrand, F.E.; McCubrey, J.A. JAK/STAT, Raf/MEK/ERK, PI3K/Akt and BCR-ABL in cell cycle progression and leukemogenesis. Leukemia 2004, 18, 189-218. [CrossRef] 
27. Den Boer, M.L.; van Slegtenhorst, M.; De Menezes, R.X.; Cheok, M.H.; Buijs-Gladdines, J.G.; Peters, S.T.; Van Zutven, L.J.; Beverloo, H.B.; Van der Spek, P.J.; Escherich, G.; et al. A subtype of childhood acute lymphoblastic leukaemia with poor treatment outcome: A genome-wide classification study. Lancet Oncol. 2009, 10, 125-134. [CrossRef]

28. Mullighan, C.G.; Su, X.; Zhang, J.; Radtke, I.; Phillips, L.A.; Miller, C.B.; Ma, J.; Liu, W.; Cheng, C.; Schulman, B.A.; et al. Deletion of IKZF1 and prognosis in acute lymphoblastic leukemia. N. Engl. J. Med. 2009, 360, 470-480. [CrossRef]

29. Tasian, S.K.; Loh, M.L.; Hunger, S.P. Philadelphia chromosome-like acute lymphoblastic leukemia. Blood 2017, 130, 2064-2072. [CrossRef]

30. Reshmi, S.C.; Harvey, R.C.; Roberts, K.G.; Stonerock, E.; Smith, A.; Jenkins, H.; Chen, I.M.; Valentine, M.; Liu, Y.; Li, Y.; et al. Targetable kinase gene fusions in high-risk B-ALL: A study from the Children's Oncology Group. Blood 2017, 129, 3352-3361. [CrossRef]

31. Yoda, A.; Yoda, Y.; Chiaretti, S.; Bar-Natan, M.; Mani, K.; Rodig, S.J.; West, N.; Xiao, Y.; Brown, J.R.; Mitsiades, C.; et al. Functional screening identifies CRLF2 in precursor B-cell acute lymphoblastic leukemia. Proc. Natl. Acad. Sci. USA 2010, 107, 252-257. [CrossRef] [PubMed]

32. van der Veer, A.; Waanders, E.; Pieters, R.; Willemse, M.E.; Van Reijmersdal, S.V.; Russell, L.J.; Harrison, C.J.; Evans, W.E.; van der Velden, V.H.; Hoogerbrugge, P.M.; et al. Independent prognostic value of BCR-ABL1-like signature and IKZF1 deletion, but not high CRLF2 expression, in children with B-cell precursor ALL. Blood 2013, 122, 2622-2629. [CrossRef] [PubMed]

33. Shiraz, P.; Payne, K.J.; Muffly, L. The Current Genomic and Molecular Landscape of Philadelphia-like Acute Lymphoblastic Leukemia. Int. J. Mol. Sci. 2020, 21, 2193. [CrossRef] [PubMed]

34. Kobayashi, K.; Miyagawa, N.; Mitsui, K.; Matsuoka, M.; Kojima, Y.; Takahashi, H.; Ootsubo, K.; Nagai, J.; Ueno, H.; Ishibashi, T.; et al. TKI dasatinib monotherapy for a patient with Ph-like ALL bearing ATF7IP/PDGFRB translocation. Pediatr. Blood Cancer 2015, 62, 1058-1060. [CrossRef]

35. Lengline, E.; Beldjord, K.; Dombret, H.; Soulier, J.; Boissel, N.; Clappier, E. Successful tyrosine kinase inhibitor therapy in a refractory B-cell precursor acute lymphoblastic leukemia with EBF1-PDGFRB fusion. Haematologica 2013, 98, e146-e148. [CrossRef]

36. Schwab, C.; Ryan, S.L.; Chilton, L.; Elliott, A.; Murray, J.; Richardson, S.; Wragg, C.; Moppett, J.; Cummins, M.; Tunstall, O; et al. EBF1-PDGFRB fusion in pediatric B-cell precursor acute lymphoblastic leukemia (BCP-ALL): Genetic profile and clinical implications. Blood 2016, 127, 2214-2218. [CrossRef]

37. Weston, B.W.; Hayden, M.A.; Roberts, K.G.; Bowyer, S.; Hsu, J.; Fedoriw, G.; Rao, K.W.; Mullighan, C.G. Tyrosine kinase inhibitor therapy induces remission in a patient with refractory EBF1-PDGFRB-positive acute lymphoblastic leukemia. J. Clin. Oncol. 2013, 31, e413-e416. [CrossRef]

38. Boer, J.M.; Marchante, J.R.; Evans, W.E.; Horstmann, M.A.; Escherich, G.; Pieters, R.; Den Boer, M.L. BCR-ABL1-like cases in pediatric acute lymphoblastic leukemia: A comparison between DCOG/Erasmus MC and COG/St. Jude signatures. Haematologica 2015, 100, e354-e357. [CrossRef]

39. Strefford, J.C.; van Delft, F.W.; Robinson, H.M.; Worley, H.; Yiannikouris, O.; Selzer, R.; Richmond, T.; Hann, I.; Bellotti, T.; Raghavan, M.; et al. Complex genomic alterations and gene expression in acute lymphoblastic leukemia with intrachromosomal amplification of chromosome 21. Proc. Natl. Acad. Sci. USA 2006, 103, 8167-8172. [CrossRef]

40. Harrison, C.J.; Moorman, A.V.; Schwab, C.; Carroll, A.J.; Raetz, E.A.; Devidas, M.; Strehl, S.; Nebral, K.; Harbott, J.; Teigler-Schlegel, A.; et al. An international study of intrachromosomal amplification of chromosome 21 (iAMP21): Cytogenetic characterization and outcome. Leukemia 2014, 28, 1015-1021. [CrossRef]

41. Rand, V.; Parker, H.; Russell, L.J.; Schwab, C.; Ensor, H.; Irving, J.; Jones, L.; Masic, D.; Minto, L.; Morrison, H.; et al. Genomic characterization implicates iAMP21 as a likely primary genetic event in childhood B-cell precursor acute lymphoblastic leukemia. Blood 2011, 117, 6848-6855. [CrossRef] [PubMed]

42. Ryan, S.L.; Matheson, E.; Grossmann, V.; Sinclair, P.; Bashton, M.; Schwab, C.; Towers, W.; Partington, M.; Elliott, A.; Minto, L.; et al. The role of the RAS pathway in iAMP21-ALL. Leukemia 2016, 30, 1824-1831. [CrossRef] [PubMed]

43. Breitbart, R.E.; Liang, C.S.; Smoot, L.B.; Laheru, D.A.; Mahdavi, V.; Nadal-Ginard, B. A fourth human MEF2 transcription factor, hMEF2D, is an early marker of the myogenic lineage. Development 1993, 118, 1095-1106. [PubMed] 
44. Mao, Z.; Bonni, A.; Xia, F.; Nadal-Vicens, M.; Greenberg, M.E. Neuronal activity-dependent cell survival mediated by transcription factor MEF2. Science 1999, 286, 785-790. [CrossRef] [PubMed]

45. Miska, E.A.; Karlsson, C.; Langley, E.; Nielsen, S.J.; Pines, J.; Kouzarides, T. HDAC4 deacetylase associates with and represses the MEF2 transcription factor. EMBO J. 1999, 18, 5099-5107. [CrossRef] [PubMed]

46. Herglotz, J.; Unrau, L.; Hauschildt, F.; Fischer, M.; Kriebitzsch, N.; Alawi, M.; Indenbirken, D.; Spohn, M.; Muller, U.; Ziegler, M.; et al. Essential control of early B-cell development by Mef2 transcription factors. Blood 2016, 127, 572-581. [CrossRef]

47. Gu, Z.; Churchman, M.; Roberts, K.; Li, Y.; Liu, Y.; Harvey, R.C.; McCastlain, K.; Reshmi, S.C.; Payne-Turner, D.; Iacobucci, I.; et al. Genomic analyses identify recurrent MEF2D fusions in acute lymphoblastic leukaemia. Nat. Commun. 2016, 7, 13331. [CrossRef]

48. Suzuki, K.; Okuno, Y.; Kawashima, N.; Muramatsu, H.; Okuno, T.; Wang, X.; Kataoka, S.; Sekiya, Y.; Hamada, M.; Murakami, N.; et al. MEF2D-BCL9 Fusion Gene Is Associated with High-Risk Acute B-Cell Precursor Lymphoblastic Leukemia in Adolescents. J. Clin. Oncol. 2016, 34, 3451-3459. [CrossRef]

49. Chiarini, F.; Paganelli, F.; Martelli, A.M.; Evangelisti, C. The Role Played by Wnt/beta-Catenin Signaling Pathway in Acute Lymphoblastic Leukemia. Int. J. Mol. Sci. 2020, 21, 1098. [CrossRef]

50. Majidinia, M.; Aghazadeh, J.; Jahanban-Esfahlani, R.; Yousefi, B. The roles of Wnt/beta-catenin pathway in tissue development and regenerative medicine. J. Cell Physiol 2018, 233, 5598-5612. [CrossRef]

51. Lento, W.; Congdon, K.; Voermans, C.; Kritzik, M.; Reya, T. Wnt signaling in normal and malignant hematopoiesis. Cold Spring Harb. Perspect. Biol. 2013, 5, a008011. [CrossRef]

52. Trautmann, M.; Sievers, E.; Aretz, S.; Kindler, D.; Michels, S.; Friedrichs, N.; Renner, M.; Kirfel, J.; Steiner, S.; Huss, S.; et al. SS18-SSX fusion protein-induced Wnt/beta-catenin signaling is a therapeutic target in synovial sarcoma. Oncogene 2014, 33, 5006-5016. [CrossRef]

53. Cironi, L.; Petricevic, T.; Fernandes Vieira, V.; Provero, P.; Fusco, C.; Cornaz, S.; Fregni, G.; Letovanec, I.; Aguet, M.; Stamenkovic, I. The fusion protein SS18-SSX1 employs core Wnt pathway transcription factors to induce a partial Wnt signature in synovial sarcoma. Sci. Rep. 2016, 6, 22113. [CrossRef]

54. Barham, W.; Frump, A.L.; Sherrill, T.P.; Garcia, C.B.; Saito-Diaz, K.; VanSaun, M.N.; Fingleton, B.; Gleaves, L.; Orton, D.; Capecchi, M.R.; et al. Targeting the Wnt pathway in synovial sarcoma models. Cancer Discov. 2013, 3, 1286-1301. [CrossRef]

55. Mani, M.; Carrasco, D.E.; Zhang, Y.; Takada, K.; Gatt, M.E.; Dutta-Simmons, J.; Ikeda, H.; Diaz-Griffero, F.; Pena-Cruz, V.; Bertagnolli, M.; et al. BCL9 promotes tumor progression by conferring enhanced proliferative, metastatic, and angiogenic properties to cancer cells. Cancer Res. 2009, 69, 7577-7586. [CrossRef]

56. Nakamoto, T.; Inagawa, H.; Takagi, K.; Soma, G. A new method of antitumor therapy with a high dose of TNF perfusion for unresectable liver tumors. Anticancer Res. 2000, 20, 4087-4096.

57. Shago, M.; Abla, O.; Hitzler, J.; Weitzman, S.; Abdelhaleem, M. Frequency and outcome of pediatric acute lymphoblastic leukemia with ZNF384 gene rearrangements including a novel translocation resulting in an ARID1B/ZNF384 gene fusion. Pediatr. Blood Cancer 2016, 63, 1915-1921. [CrossRef]

58. Hirabayashi, S.; Ohki, K.; Nakabayashi, K.; Ichikawa, H.; Momozawa, Y.; Okamura, K.; Yaguchi, A.; Terada, K.; Saito, Y.; Yoshimi, A.; et al. ZNF384-related fusion genes define a subgroup of childhood B-cell precursor acute lymphoblastic leukemia with a characteristic immunotype. Haematologica 2017, 102, 118-129. [CrossRef]

59. Qian, M.; Zhang, H.; Kham, S.K.; Liu, S.; Jiang, C.; Zhao, X.; Lu, Y.; Goodings, C.; Lin, T.N.; Zhang, R.; et al. Whole-transcriptome sequencing identifies a distinct subtype of acute lymphoblastic leukemia with predominant genomic abnormalities of EP300 and CREBBP. Genome Res. 2017, 27, 185-195. [CrossRef]

60. Gocho, Y.; Kiyokawa, N.; Ichikawa, H.; Nakabayashi, K.; Osumi, T.; Ishibashi, T.; Ueno, H.; Terada, K.; Oboki, K.; Sakamoto, H.; et al. A novel recurrent EP300-ZNF384 gene fusion in B-cell precursor acute lymphoblastic leukemia. Leukemia 2015, 29, 2445-2448. [CrossRef]

61. Dutta, R.; Tiu, B.; Sakamoto, K.M. CBP/p300 acetyltransferase activity in hematologic malignancies. Mol. Genet. Metab. 2016, 119, 37-43. [CrossRef]

62. McClure, B.J.; Heatley, S.L.; Kok, C.H.; Sadras, T.; An, J.; Hughes, T.P.; Lock, R.B.; Yeung, D.; Sutton, R.; White, D.L. Pre-B acute lymphoblastic leukaemia recurrent fusion, EP300-ZNF384, is associated with a distinct gene expression. Br. J. Cancer 2018, 118, 1000-1004. [CrossRef] 
63. Lilljebjorn, H.; Henningsson, R.; Hyrenius-Wittsten, A.; Olsson, L.; Orsmark-Pietras, C.; von Palffy, S.; Askmyr, M.; Rissler, M.; Schrappe, M.; Cario, G.; et al. Identification of ETV6-RUNX1-like and DUX4-rearranged subtypes in paediatric B-cell precursor acute lymphoblastic leukaemia. Nat. Commun. 2016, 7, 11790. [CrossRef]

64. Yasuda, T.; Tsuzuki, S.; Kawazu, M.; Hayakawa, F.; Kojima, S.; Ueno, T.; Imoto, N.; Kohsaka, S.; Kunita, A.; Doi, K.; et al. Recurrent DUX4 fusions in B cell acute lymphoblastic leukemia of adolescents and young adults. Nat. Genet. 2016, 48, 569-574. [CrossRef]

65. Zhang, J.; McCastlain, K.; Yoshihara, H.; Xu, B.; Chang, Y.; Churchman, M.L.; Wu, G.; Li, Y.; Wei, L.; Iacobucci, I.; et al. Deregulation of DUX4 and ERG in acute lymphoblastic leukemia. Nat. Genet. 2016, 48, 1481-1489. [CrossRef]

66. Iacobucci, I.; Li, Y.; Roberts, K.G.; Dobson, S.M.; Kim, J.C.; Payne-Turner, D.; Harvey, R.C.; Valentine, M.; McCastlain, K.; Easton, J.; et al. Truncating Erythropoietin Receptor Rearrangements in Acute Lymphoblastic Leukemia. Cancer Cell 2016, 29, 186-200. [CrossRef]

67. Dib, C.; Zakharova, V.; Popova, E.; Kiseleva, E.; Chernyak, B.; Lipinski, M.; Vassetzky, Y.S. DUX4 Pathological Expression: Causes and Consequences in Cancer. Trends Cancer 2019, 5, 268-271. [CrossRef]

68. Harvey, R.C.; Mullighan, C.G.; Wang, X.; Dobbin, K.K.; Davidson, G.S.; Bedrick, E.J.; Chen, I.M.; Atlas, S.R.; Kang, H.; Ar, K.; et al. Identification of novel cluster groups in pediatric high-risk B-precursor acute lymphoblastic leukemia with gene expression profiling: Correlation with genome-wide DNA copy number alterations, clinical characteristics, and outcome. Blood 2010, 116, 4874-4884. [CrossRef]

69. Mullighan, C.G.; Goorha, S.; Radtke, I.; Miller, C.B.; Coustan-Smith, E.; Dalton, J.D.; Girtman, K.; Mathew, S.; Ma, J.; Pounds, S.B.; et al. Genome-wide analysis of genetic alterations in acute lymphoblastic leukaemia. Nature 2007, 446, 758-764. [CrossRef]

70. Gu, Z.; Churchman, M.L.; Roberts, K.G.; Moore, I.; Zhou, X.; Nakitandwe, J.; Hagiwara, K.; Pelletier, S.; Gingras, S.; Berns, H.; et al. PAX5-driven subtypes of B-progenitor acute lymphoblastic leukemia. Nat. Genet. 2019, 51, 296-307. [CrossRef]

71. Nutt, S.L.; Heavey, B.; Rolink, A.G.; Busslinger, M. Commitment to the B-lymphoid lineage depends on the transcription factor Pax5. Nature 1999, 401, 556-562. [CrossRef]

72. Schwab, C.; Nebral, K.; Chilton, L.; Leschi, C.; Waanders, E.; Boer, J.M.; Zaliova, M.; Sutton, R.; Ofverholm, I.I.; Ohki, K.; et al. Intragenic amplification of PAX5: A novel subgroup in B-cell precursor acute lymphoblastic leukemia? Blood Adv. 2017, 1, 1473-1477. [CrossRef]

73. Nebral, K.; Denk, D.; Attarbaschi, A.; Konig, M.; Mann, G.; Haas, O.A.; Strehl, S. Incidence and diversity of PAX5 fusion genes in childhood acute lymphoblastic leukemia. Leukemia 2009, 23, 134-143. [CrossRef]

74. Liu, G.J.; Cimmino, L.; Jude, J.G.; Hu, Y.; Witkowski, M.T.; McKenzie, M.D.; Kartal-Kaess, M.; Best, S.A.; Tuohey, L.; Liao, Y.; et al. Pax5 loss imposes a reversible differentiation block in B-progenitor acute lymphoblastic leukemia. Genes Dev. 2014, 28, 1337-1350. [CrossRef]

75. Heltemes-Harris, L.M.; Willette, M.J.; Ramsey, L.B.; Qiu, Y.H.; Neeley, E.S.; Zhang, N.; Thomas, D.A.; Koeuth, T.; Baechler, E.C.; Kornblau, S.M.; et al. Ebf1 or Pax5 haploinsufficiency synergizes with STAT5 activation to initiate acute lymphoblastic leukemia. J. Exp. Med. 2011, 208, 1135-1149. [CrossRef]

76. Ott, C.J.; Kopp, N.; Bird, L.; Paranal, R.M.; Qi, J.; Bowman, T.; Rodig, S.J.; Kung, A.L.; Bradner, J.E.; Weinstock, D.M. BET bromodomain inhibition targets both c-Myc and IL7R in high-risk acute lymphoblastic leukemia. Blood 2012, 120, 2843-2852. [CrossRef]

77. Da Costa, D.; Agathanggelou, A.; Perry, T.; Weston, V.; Petermann, E.; Zlatanou, A.; Oldreive, C.; Wei, W.; Stewart, G.; Longman, J.; et al. BET inhibition as a single or combined therapeutic approach in primary paediatric B-precursor acute lymphoblastic leukaemia. Blood Cancer J. 2013, 3, e126. [CrossRef]

78. Dang, J.; Wei, L.; de Ridder, J.; Su, X.; Rust, A.G.; Roberts, K.G.; Payne-Turner, D.; Cheng, J.; Ma, J.; Qu, C.; et al. PAX5 is a tumor suppressor in mouse mutagenesis models of acute lymphoblastic leukemia. Blood 2015, 125, 3609-3617. [CrossRef]

79. Liu, S.; Walker, S.R.; Nelson, E.A.; Cerulli, R.; Xiang, M.; Toniolo, P.A.; Qi, J.; Stone, R.M.; Wadleigh, M.; Bradner, J.E.; et al. Targeting STAT5 in hematologic malignancies through inhibition of the bromodomain and extra-terminal (BET) bromodomain protein BRD2. Mol. Cancer Ther. 2014, 13, 1194-1205. [CrossRef]

80. Passet, M.; Boissel, N.; Sigaux, F.; Saillard, C.; Bargetzi, M.; Ba, I.; Thomas, X.; Graux, C.; Chalandon, Y.; Leguay, T.; et al. PAX5 P80R mutation identifies a novel subtype of B-cell precursor acute lymphoblastic leukemia with favorable outcome. Blood 2019, 133, 280-284. [CrossRef] 
81. Li, J.F.; Dai, Y.T.; Lilljebjorn, H.; Shen, S.H.; Cui, B.W.; Bai, L.; Liu, Y.F.; Qian, M.X.; Kubota, Y.; Kiyoi, H.; et al. Transcriptional landscape of B cell precursor acute lymphoblastic leukemia based on an international study of 1,223 cases. Proc. Natl. Acad. Sci. USA 2018, 115, E11711-E11720. [CrossRef] [PubMed]

82. Shah, S.; Schrader, K.A.; Waanders, E.; Timms, A.E.; Vijai, J.; Miething, C.; Wechsler, J.; Yang, J.; Hayes, J.; Klein, R.J.; et al. A recurrent germline PAX5 mutation confers susceptibility to pre-B cell acute lymphoblastic leukemia. Nat. Genet. 2013, 45, 1226-1231. [CrossRef] [PubMed]

83. Auer, F.; Ruschendorf, F.; Gombert, M.; Husemann, P.; Ginzel, S.; Izraeli, S.; Harit, M.; Weintraub, M.; Weinstein, O.Y.; Lerer, I.; et al. Inherited susceptibility to pre B-ALL caused by germline transmission of PAX5 c.547G>A. Leukemia 2014, 28, 1136-1138. [CrossRef] [PubMed]

84. Schultz, K.R.; Pullen, D.J.; Sather, H.N.; Shuster, J.J.; Devidas, M.; Borowitz, M.J.; Carroll, A.J.; Heerema, N.A.; Rubnitz, J.E.; Loh, M.L.; et al. Risk- and response-based classification of childhood B-precursor acute lymphoblastic leukemia: A combined analysis of prognostic markers from the Pediatric Oncology Group (POG) and Children's Cancer Group (CCG). Blood 2007, 109, 926-935. [CrossRef] [PubMed]

85. Zaliova, M.; Kotrova, M.; Bresolin, S.; Stuchly, J.; Stary, J.; Hrusak, O.; Te Kronnie, G.; Trka, J.; Zuna, J.; Vaskova, M. ETV6/RUNX1-like acute lymphoblastic leukemia: A novel B-cell precursor leukemia subtype associated with the CD27/CD44 immunophenotype. Genes Chromosomes Cancer 2017, 56, 608-616. [CrossRef] [PubMed]

86. Vaskova, M.; Fronkova, E.; Starkova, J.; Kalina, T.; Mejstrikova, E.; Hrusak, O. CD44 and CD27 delineate B-precursor stages with different recombination status and with an uneven distribution in nonmalignant and malignant hematopoiesis. Tissue Antigens 2008, 71, 57-66. [CrossRef]

87. Zaliova, M.; Stuchly, J.; Winkowska, L.; Musilova, A.; Fiser, K.; Slamova, M.; Starkova, J.; Vaskova, M.; Hrusak, O.; Sramkova, L.; et al. Genomic landscape of pediatric B-other acute lymphoblastic leukemia in a consecutive European cohort. Haematologica 2019, 104, 1396-1406. [CrossRef]

88. Hormann, F.M.; Hoogkamer, A.Q.; Beverloo, H.B.; Boeree, A.; Dingjan, I.; Wattel, M.M.; Stam, R.W.; Escherich, G.; Pieters, R.; den Boer, M.L.; et al. NUTM1 is a recurrent fusion gene partner in B-cell precursor acute lymphoblastic leukemia associated with increased expression of genes on chromosome band 10p12.31-12.2. Haematologica 2019, 104, e455-e459. [CrossRef]

89. Alekseyenko, A.A.; Walsh, E.M.; Wang, X.; Grayson, A.R.; Hsi, P.T.; Kharchenko, P.V.; Kuroda, M.I.; French, C.A. The oncogenic BRD4-NUT chromatin regulator drives aberrant transcription within large topological domains. Genes Dev. 2015, 29, 1507-1523. [CrossRef]

90. French, C.A. NUT Carcinoma: Clinicopathologic features, pathogenesis, and treatment. Pathol Int. 2018, 68, 583-595. [CrossRef]

91. French, C. NUT midline carcinoma. Nat. Rev. Cancer 2014, 14, 149-150. [CrossRef] [PubMed]

92. Stathis, A.; Zucca, E.; Bekradda, M.; Gomez-Roca, C.; Delord, J.P.; de La Motte Rouge, T.; Uro-Coste, E.; de Braud, F.; Pelosi, G.; French, C.A. Clinical Response of Carcinomas Harboring the BRD4-NUT Oncoprotein to the Targeted Bromodomain Inhibitor OTX015/MK-8628. Cancer Discov. 2016, 6, 492-500. [CrossRef] [PubMed]

93. Downward, J. Targeting RAS signalling pathways in cancer therapy. Nat. Rev. Cancer 2003, 3, 11-22. [CrossRef] [PubMed]

94. Oshima, K.; Khiabanian, H.; da Silva-Almeida, A.C.; Tzoneva, G.; Abate, F.; Ambesi-Impiombato, A.; Sanchez-Martin, M.; Carpenter, Z.; Penson, A.; Perez-Garcia, A.; et al. Mutational landscape, clonal evolution patterns, and role of RAS mutations in relapsed acute lymphoblastic leukemia. Proc. Natl. Acad. Sci. USA 2016, 113, 11306-11311. [CrossRef]

95. Jerchel, I.S.; Hoogkamer, A.Q.; Aries, I.M.; Steeghs, E.M.P.; Boer, J.M.; Besselink, N.J.M.; Boeree, A.; van de Ven, C.; de Groot-Kruseman, H.A.; de Haas, V.; et al. RAS pathway mutations as a predictive biomarker for treatment adaptation in pediatric B-cell precursor acute lymphoblastic leukemia. Leukemia 2018, 32, 931-940. [CrossRef] [PubMed]

96. Fischer, U.; Forster, M.; Rinaldi, A.; Risch, T.; Sungalee, S.; Warnatz, H.J.; Bornhauser, B.; Gombert, M.; Kratsch, C.; Stutz, A.M.; et al. Genomics and drug profiling of fatal TCF3-HLF-positive acute lymphoblastic leukemia identifies recurrent mutation patterns and therapeutic options. Nat. Genet. 2015, 47, 1020-1029. [CrossRef] 
97. Irving, J.; Matheson, E.; Minto, L.; Blair, H.; Case, M.; Halsey, C.; Swidenbank, I.; Ponthan, F.; Kirschner-Schwabe, R.; Groeneveld-Krentz, S.; et al. Ras pathway mutations are prevalent in relapsed childhood acute lymphoblastic leukemia and confer sensitivity to MEK inhibition. Blood 2014, 124, 3420-3430. [CrossRef] [PubMed]

98. Irving, J.A.; Enshaei, A.; Parker, C.A.; Sutton, R.; Kuiper, R.P.; Erhorn, A.; Minto, L.; Venn, N.C.; Law, T.; $\mathrm{Yu}$, J.; et al. Integration of genetic and clinical risk factors improves prognostication in relapsed childhood B-cell precursor acute lymphoblastic leukemia. Blood 2016, 128, 911-922. [CrossRef]

99. Ma, X.; Edmonson, M.; Yergeau, D.; Muzny, D.M.; Hampton, O.A.; Rusch, M.; Song, G.; Easton, J.; Harvey, R.C.; Wheeler, D.A.; et al. Rise and fall of subclones from diagnosis to relapse in pediatric B-acute lymphoblastic leukaemia. Nat. Commun. 2015, 6, 6604. [CrossRef]

100. McCubrey, J.A.; Steelman, L.S.; Franklin, R.A.; Abrams, S.L.; Chappell, W.H.; Wong, E.W.; Lehmann, B.D.; Terrian, D.M.; Basecke, J.; Stivala, F.; et al. Targeting the RAF/MEK/ERK, PI3K/AKT and p53 pathways in hematopoietic drug resistance. Adv. Enzym. Regul. 2007, 47, 64-103. [CrossRef]

101. Aries, I.M.; van den Dungen, R.E.; Koudijs, M.J.; Cuppen, E.; Voest, E.; Molenaar, J.J.; Caron, H.N.; Pieters, R.; den Boer, M.L. Towards personalized therapy in pediatric acute lymphoblastic leukemia: RAS mutations and prednisolone resistance. Haematologica 2015, 100, e132-e136. [CrossRef] [PubMed]

102. Evangelisti, C.; Chiarini, F.; Paganelli, F.; Marmiroli, S.; Martelli, A.M. Crosstalks of GSK3 signaling with the mTOR network and effects on targeted therapy of cancer. Biochim. Biophys. Acta Mol. Cell Res. 2020, 1867, 118635. [CrossRef] [PubMed]

103. Gomes, A.M.; Soares, M.V.; Ribeiro, P.; Caldas, J.; Povoa, V.; Martins, L.R.; Melao, A.; Serra-Caetano, A.; de Sousa, A.B.; Lacerda, J.F.; et al. Adult B-cell acute lymphoblastic leukemia cells display decreased PTEN activity and constitutive hyperactivation of PI3K/Akt pathway despite high PTEN protein levels. Haematologica 2014, 99, 1062-1068. [CrossRef] [PubMed]

104. Martelli, A.M.; Chiarini, F.; Evangelisti, C.; Cappellini, A.; Buontempo, F.; Bressanin, D.; Fini, M.; McCubrey, J.A. Two hits are better than one: Targeting both phosphatidylinositol 3-kinase and mammalian target of rapamycin as a therapeutic strategy for acute leukemia treatment. Oncotarget 2012, 3, 371-394. [CrossRef]

105. Tasian, S.K.; Teachey, D.T.; Rheingold, S.R. Targeting the PI3K/mTOR Pathway in Pediatric Hematologic Malignancies. Front. Oncol. 2014, 4, 108. [CrossRef]

106. Chiarini, F.; Evangelisti, C.; Lattanzi, G.; McCubrey, J.A.; Martelli, A.M. Advances in understanding the mechanisms of evasive and innate resistance to mTOR inhibition in cancer cells. Biochim. Biophys. Acta Mol. Cell Res. 2019, 1866, 1322-1337. [CrossRef]

107. Lee, J.S.; Vo, T.T.; Fruman, D.A. Targeting mTOR for the treatment of B cell malignancies. Br. J. Clin. Pharmacol. 2016, 82, 1213-1228. [CrossRef]

108. Simioni, C.; Martelli, A.M.; Zauli, G.; Vitale, M.; McCubrey, J.A.; Capitani, S.; Neri, L.M. Targeting the phosphatidylinositol 3-kinase/Akt/mechanistic target of rapamycin signaling pathway in B-lineage acute lymphoblastic leukemia: An update. J. Cell Physiol. 2018, 233, 6440-6454. [CrossRef]

109. Tasian, S.K.; Doral, M.Y.; Borowitz, M.J.; Wood, B.L.; Chen, I.M.; Harvey, R.C.; Gastier-Foster, J.M.; Willman, C.L.; Hunger, S.P.; Mullighan, C.G.; et al. Aberrant STAT5 and PI3K/mTOR pathway signaling occurs in human CRLF2-rearranged B-precursor acute lymphoblastic leukemia. Blood 2012, 120, 833-842. [CrossRef]

110. Maude, S.L.; Tasian, S.K.; Vincent, T.; Hall, J.W.; Sheen, C.; Roberts, K.G.; Seif, A.E.; Barrett, D.M.; Chen, I.M.; Collins, J.R.; et al. Targeting JAK1/2 and mTOR in murine xenograft models of Ph-like acute lymphoblastic leukemia. Blood 2012, 120, 3510-3518. [CrossRef]

111. Zhang, Q.; Shi, C.; Han, L.; Jain, N.; Roberts, K.G.; Ma, H.; Cai, T.; Cavazos, A.; Tabe, Y.; Jacamo, R.O.; et al. Inhibition of mTORC1/C2 signaling improves anti-leukemia efficacy of JAK/STAT blockade in CRLF2 rearranged and/or JAK driven Philadelphia chromosome-like acute B-cell lymphoblastic leukemia. Oncotarget 2018, 9, 8027-8041. [CrossRef] [PubMed]

112. Hatzivassiliou, G.; Haling, J.R.; Chen, H.; Song, K.; Price, S.; Heald, R.; Hewitt, J.F.; Zak, M.; Peck, A.; Orr, C.; et al. Mechanism of MEK inhibition determines efficacy in mutant KRAS- versus BRAF-driven cancers. Nature 2013, 501, 232-236. [CrossRef] [PubMed] 
113. Jones, C.L.; Gearheart, C.M.; Fosmire, S.; Delgado-Martin, C.; Evensen, N.A.; Bride, K.; Waanders, A.J.; Pais, F.; Wang, J.; Bhatla, T.; et al. MAPK signaling cascades mediate distinct glucocorticoid resistance mechanisms in pediatric leukemia. Blood 2015, 126, 2202-2212. [CrossRef] [PubMed]

114. Rambal, A.A.; Panaguiton, Z.L.; Kramer, L.; Grant, S.; Harada, H. MEK inhibitors potentiate dexamethasone lethality in acute lymphoblastic leukemia cells through the pro-apoptotic molecule BIM. Leukemia 2009, 23, 1744-1754. [CrossRef] [PubMed]

115. Niehrs, C. The complex world of WNT receptor signalling. Nat. Rev. Mol. Cell Biol. 2012, 13, 767-779. [CrossRef]

116. Luis, T.C.; Ichii, M.; Brugman, M.H.; Kincade, P.; Staal, F.J. Wnt signaling strength regulates normal hematopoiesis and its deregulation is involved in leukemia development. Leukemia 2012, 26, 414-421. [CrossRef]

117. Park, E.; Gang, E.J.; Hsieh, Y.T.; Schaefer, P.; Chae, S.; Klemm, L.; Huantes, S.; Loh, M.; Conway, E.M.; Kang, E.S.; et al. Targeting survivin overcomes drug resistance in acute lymphoblastic leukemia. Blood 2011, 118, 2191-2199. [CrossRef]

118. Morrison, D.J.; Hogan, L.E.; Condos, G.; Bhatla, T.; Germino, N.; Moskowitz, N.P.; Lee, L.; Bhojwani, D.; Horton, T.M.; Belitskaya-Levy, I.; et al. Endogenous knockdown of survivin improves chemotherapeutic response in ALL models. Leukemia 2012, 26, 271-279. [CrossRef]

119. Khan, N.I.; Bradstock, K.F.; Bendall, L.J. Activation of Wnt/beta-catenin pathway mediates growth and survival in B-cell progenitor acute lymphoblastic leukaemia. Br. J. Haematol. 2007, 138, 338-348. [CrossRef]

120. Petropoulos, K.; Arseni, N.; Schessl, C.; Stadler, C.R.; Rawat, V.P.; Deshpande, A.J.; Heilmeier, B.; Hiddemann, W.; Quintanilla-Martinez, L.; Bohlander, S.K.; et al. A novel role for Lef-1, a central transcription mediator of Wnt signaling, in leukemogenesis. J. Exp. Med. 2008, 205, 515-522. [CrossRef]

121. Kuhnl, A.; Gokbuget, N.; Kaiser, M.; Schlee, C.; Stroux, A.; Burmeister, T.; Mochmann, L.H.; Hoelzer, D.; Hofmann, W.K.; Thiel, E.; et al. Overexpression of LEF1 predicts unfavorable outcome in adult patients with B-precursor acute lymphoblastic leukemia. Blood 2011, 118, 6362-6367. [CrossRef] [PubMed]

122. Yang, Y.; Mallampati, S.; Sun, B.; Zhang, J.; Kim, S.B.; Lee, J.S.; Gong, Y.; Cai, Z.; Sun, X. Wnt pathway contributes to the protection by bone marrow stromal cells of acute lymphoblastic leukemia cells and is a potential therapeutic target. Cancer Lett. 2013, 333, 9-17. [CrossRef] [PubMed]

123. Dandekar, S.; Romanos-Sirakis, E.; Pais, F.; Bhatla, T.; Jones, C.; Bourgeois, W.; Hunger, S.P.; Raetz, E.A.; Hermiston, M.L.; Dasgupta, R.; et al. Wnt inhibition leads to improved chemosensitivity in paediatric acute lymphoblastic leukaemia. Br. J. Haematol. 2014, 167, 87-99. [CrossRef] [PubMed]

124. Gang, E.J.; Hsieh, Y.T.; Pham, J.; Zhao, Y.; Nguyen, C.; Huantes, S.; Park, E.; Naing, K.; Klemm, L.; Swaminathan, S.; et al. Small-molecule inhibition of CBP/catenin interactions eliminates drug-resistant clones in acute lymphoblastic leukemia. Oncogene 2014, 33, 2169-2178. [CrossRef]

125. Raetz, E.A.; Morrison, D.; Romanos-Sirakis, E.; Gaynon, P.; Sposto, R.; Bhojwani, D.; Bostrom, B.C.; Brown, P.; Eckroth, E.; Cassar, J.; et al. A phase I study of EZN-3042, a novel survivin messenger ribonucleic acid (mRNA) antagonist, administered in combination with chemotherapy in children with relapsed acute lymphoblastic leukemia (ALL): A report from the therapeutic advances in childhood leukemia and lymphoma (TACL) consortium. J. Pediatr. Hematol. Oncol. 2014, 36, 458-463. [CrossRef]

126. McWhirter, J.R.; Neuteboom, S.T.; Wancewicz, E.V.; Monia, B.P.; Downing, J.R.; Murre, C. Oncogenic homeodomain transcription factor E2A-Pbx1 activates a novel WNT gene in pre-B acute lymphoblastoid leukemia. Proc. Natl. Acad. Sci. USA 1999, 96, 11464-11469. [CrossRef]

127. Karvonen, H.; Perttila, R.; Niininen, W.; Hautanen, V.; Barker, H.; Murumagi, A.; Heckman, C.A.; Ungureanu, D. Wnt5a and ROR1 activate non-canonical Wnt signaling via RhoA in TCF3-PBX1 acute lymphoblastic leukemia and highlight new treatment strategies via Bcl-2 co-targeting. Oncogene 2019, 38, 3288-3300. [CrossRef]

128. Mazieres, J.; You, L.; He, B.; Xu, Z.; Lee, A.Y.; Mikami, I.; McCormick, F.; Jablons, D.M. Inhibition of Wnt16 in human acute lymphoblastoid leukemia cells containing the $t(1 ; 19)$ translocation induces apoptosis. Oncogene 2005, 24, 5396-5400. [CrossRef] 
129. Martin, V.; Agirre, X.; Jimenez-Velasco, A.; Jose-Eneriz, E.S.; Cordeu, L.; Garate, L.; Vilas-Zornoza, A.; Castillejo, J.A.; Heiniger, A.; Prosper, F.; et al. Methylation status of Wnt signaling pathway genes affects the clinical outcome of Philadelphia-positive acute lymphoblastic leukemia. Cancer Sci. 2008, 99, 1865-1868. [CrossRef]

130. Ahmad, I.; Patel, R.; Liu, Y.; Singh, L.B.; Taketo, M.M.; Wu, X.R.; Leung, H.Y.; Sansom, O.J. Ras mutation cooperates with beta-catenin activation to drive bladder tumourigenesis. Cell Death Dis. 2011, 2, e124. [CrossRef]

131. Park, K.S.; Jeon, S.H.; Kim, S.E.; Bahk, Y.Y.; Holmen, S.L.; Williams, B.O.; Chung, K.C.; Surh, Y.J.; Choi, K.Y. APC inhibits ERK pathway activation and cellular proliferation induced by RAS. J. Cell Sci. 2006, 119, 819-827. [CrossRef] [PubMed]

132. Hogan, L.E.; Meyer, J.A.; Yang, J.; Wang, J.; Wong, N.; Yang, W.; Condos, G.; Hunger, S.P.; Raetz, E.; Saffery, R.; et al. Integrated genomic analysis of relapsed childhood acute lymphoblastic leukemia reveals therapeutic strategies. Blood 2011, 118, 5218-5226. [CrossRef] [PubMed]

133. Menendez, P.; Vargas, A.; Bueno, C.; Barrena, S.; Almeida, J.; De Santiago, M.; Lopez, A.; Roa, S.; San Miguel, J.F.; Orfao, A. Quantitative analysis of bcl-2 expression in normal and leukemic human B-cell differentiation. Leukemia 2004, 18, 491-498. [CrossRef] [PubMed]

134. Roberts, A.W.; Davids, M.S.; Pagel, J.M.; Kahl, B.S.; Puvvada, S.D.; Gerecitano, J.F.; Kipps, T.J.; Anderson, M.A.; Brown, J.R.; Gressick, L.; et al. Targeting BCL2 with Venetoclax in Relapsed Chronic Lymphocytic Leukemia. N. Engl. J. Med. 2016, 374, 311-322. [CrossRef] [PubMed]

135. Scheffold, A.; Jebaraj, B.M.C.; Stilgenbauer, S. Venetoclax: Targeting BCL2 in Hematological Cancers. Recent Results Cancer Res. 2018, 212, 215-242. [CrossRef]

136. Vogler, M.; Dinsdale, D.; Dyer, M.J.; Cohen, G.M. ABT-199 selectively inhibits BCL2 but not BCL2L1 and efficiently induces apoptosis of chronic lymphocytic leukaemic cells but not platelets. Br. J. Haematol. 2013, 163, 139-142. [CrossRef]

137. Jones, L.; Carol, H.; Evans, K.; Richmond, J.; Houghton, P.J.; Smith, M.A.; Lock, R.B. A review of new agents evaluated against pediatric acute lymphoblastic leukemia by the Pediatric Preclinical Testing Program. Leukemia 2016, 30, 2133-2141. [CrossRef]

138. Khaw, S.L.; Suryani, S.; Evans, K.; Richmond, J.; Robbins, A.; Kurmasheva, R.T.; Billups, C.A.; Erickson, S.W.; Guo, Y.; Houghton, P.J.; et al. Venetoclax responses of pediatric ALL xenografts reveal sensitivity of MLL-rearranged leukemia. Blood 2016, 128, 1382-1395. [CrossRef]

139. Davids, M.S.; Roberts, A.W.; Seymour, J.F.; Pagel, J.M.; Kahl, B.S.; Wierda, W.G.; Puvvada, S.; Kipps, T.J.; Anderson, M.A.; Salem, A.H.; et al. Phase I First-in-Human Study of Venetoclax in Patients with Relapsed or Refractory Non-Hodgkin Lymphoma. J. Clin. Oncol. 2017, 35, 826-833. [CrossRef]

140. Alford, S.E.; Kothari, A.; Loeff, F.C.; Eichhorn, J.M.; Sakurikar, N.; Goselink, H.M.; Saylors, R.L.; Jedema, I.; Falkenburg, J.H.; Chambers, T.C. BH3 Inhibitor Sensitivity and Bcl-2 Dependence in Primary Acute Lymphoblastic Leukemia Cells. Cancer Res. 2015, 75, 1366-1375. [CrossRef]

141. Frismantas, V.; Dobay, M.P.; Rinaldi, A.; Tchinda, J.; Dunn, S.H.; Kunz, J.; Richter-Pechanska, P.; Marovca, B.; Pail, O.; Jenni, S.; et al. Ex vivo drug response profiling detects recurrent sensitivity patterns in drug-resistant acute lymphoblastic leukemia. Blood 2017, 129, e26-e37. [CrossRef] [PubMed]

142. Deeks, E.D. Venetoclax: First Global Approval. Drugs 2016, 76, 979-987. [CrossRef] [PubMed]

143. Konopleva, M.; Pollyea, D.A.; Potluri, J.; Chyla, B.; Hogdal, L.; Busman, T.; McKeegan, E.; Salem, A.H.; Zhu, M.; Ricker, J.L.; et al. Efficacy and Biological Correlates of Response in a Phase II Study of Venetoclax Monotherapy in Patients with Acute Myelogenous Leukemia. Cancer Discov. 2016, 6, 1106-1117. [CrossRef] [PubMed]

144. Chonghaile, T.N.; Roderick, J.E.; Glenfield, C.; Ryan, J.; Sallan, S.E.; Silverman, L.B.; Loh, M.L.; Hunger, S.P.; Wood, B.; DeAngelo, D.J.; et al. Maturation stage of T-cell acute lymphoblastic leukemia determines BCL-2 versus BCL-XL dependence and sensitivity to ABT-199. Cancer Discov. 2014, 4, 1074-1087. [CrossRef]

145. Place, A.E.; Pikman, Y.; Stevenson, K.E.; Harris, M.H.; Pauly, M.; Sulis, M.L.; Hijiya, N.; Gore, L.; Cooper, T.M.; Loh, M.L.; et al. Phase I trial of the mTOR inhibitor everolimus in combination with multi-agent chemotherapy in relapsed childhood acute lymphoblastic leukemia. Pediatr. Blood Cancer 2018, 65, e27062. [CrossRef] 
146. Stefanzl, G.; Berger, D.; Cerny-Reiterer, S.; Blatt, K.; Eisenwort, G.; Sperr, W.R.; Hoermann, G.; Lind, K.; Hauswirth, A.W.; Bettelheim, P.; et al. The pan-BCL-2-blocker obatoclax (GX15-070) and the PI3-kinase/mTOR-inhibitor BEZ235 produce cooperative growth-inhibitory effects in ALL cells. Oncotarget 2017, 8, 67709-67722. [CrossRef]

147. Rahmani, M.; Nkwocha, J.; Hawkins, E.; Pei, X.; Parker, R.E.; Kmieciak, M.; Leverson, J.D.; Sampath, D.; Ferreira-Gonzalez, A.; Grant, S. Cotargeting BCL-2 and PI3K Induces BAX-Dependent Mitochondrial Apoptosis in AML Cells. Cancer Res. 2018, 78, 3075-3086. [CrossRef]

148. Ghoshal, A.; Yugandhar, D.; Srivastava, A.K. BET inhibitors in cancer therapeutics: A patent review. Expert Opin. Ther. Pat. 2016, 26, 505-522. [CrossRef]

149. Alqahtani, A.; Choucair, K.; Ashraf, M.; Hammouda, D.M.; Alloghbi, A.; Khan, T.; Senzer, N.; Nemunaitis, J. Bromodomain and extra-terminal motif inhibitors: A review of preclinical and clinical advances in cancer therapy. Future Sci. OA 2019, 5, FSO372. [CrossRef]

150. Filippakopoulos, P.; Qi, J.; Picaud, S.; Shen, Y.; Smith, W.B.; Fedorov, O.; Morse, E.M.; Keates, T.; Hickman, T.T.; Felletar, I.; et al. Selective inhibition of BET bromodomains. Nature 2010, 468, 1067-1073. [CrossRef]

151. Mertz, J.A.; Conery, A.R.; Bryant, B.M.; Sandy, P.; Balasubramanian, S.; Mele, D.A.; Bergeron, L.; Sims, R.J., 3rd. Targeting MYC dependence in cancer by inhibiting BET bromodomains. Proc. Natl. Acad. Sci. USA 2011, 108, 16669-16674. [CrossRef] [PubMed]

152. Dawson, M.A.; Kouzarides, T. Cancer epigenetics: From mechanism to therapy. Cell 2012, 150, $12-27$. [CrossRef] [PubMed]

153. Roderick, J.E.; Tesell, J.; Shultz, L.D.; Brehm, M.A.; Greiner, D.L.; Harris, M.H.; Silverman, L.B.; Sallan, S.E.; Gutierrez, A.; Look, A.T.; et al. c-Myc inhibition prevents leukemia initiation in mice and impairs the growth of relapsed and induction failure pediatric T-ALL cells. Blood 2014, 123, 1040-1050. [CrossRef] [PubMed]

154. Loosveld, M.; Castellano, R.; Gon, S.; Goubard, A.; Crouzet, T.; Pouyet, L.; Prebet, T.; Vey, N.; Nadel, B.; Collette, Y.; et al. Therapeutic targeting of c-Myc in T-cell acute lymphoblastic leukemia, T-ALL. Oncotarget 2014, 5, 3168-3172. [CrossRef] [PubMed]

155. Berthon, C.; Raffoux, E.; Thomas, X.; Vey, N.; Gomez-Roca, C.; Yee, K.; Taussig, D.C.; Rezai, K.; Roumier, C.; Herait, P.; et al. Bromodomain inhibitor OTX015 in patients with acute leukaemia: A dose-escalation, phase 1 study. Lancet Haematol. 2016, 3, e186-e195. [CrossRef]

156. Rathert, P.; Roth, M.; Neumann, T.; Muerdter, F.; Roe, J.S.; Muhar, M.; Deswal, S.; Cerny-Reiterer, S.; Peter, B.; Jude, J.; et al. Transcriptional plasticity promotes primary and acquired resistance to BET inhibition. Nature 2015, 525, 543-547. [CrossRef]

157. Fong, C.Y.; Gilan, O.; Lam, E.Y.; Rubin, A.F.; Ftouni, S.; Tyler, D.; Stanley, K.; Sinha, D.; Yeh, P.; Morison, J.; et al. BET inhibitor resistance emerges from leukaemia stem cells. Nature 2015, 525, 538-542. [CrossRef]

158. Picaud, S.; Da Costa, D.; Thanasopoulou, A.; Filippakopoulos, P.; Fish, P.V.; Philpott, M.; Fedorov, O.; Brennan, P.; Bunnage, M.E.; Owen, D.R.; et al. PFI-1, a highly selective protein interaction inhibitor, targeting BET Bromodomains. Cancer Res. 2013, 73, 3336-3346. [CrossRef]

159. Lens, S.M.; Voest, E.E.; Medema, R.H. Shared and separate functions of polo-like kinases and aurora kinases in cancer. Nat. Rev. Cancer 2010, 10, 825-841. [CrossRef]

160. Ceribelli, M.; Kelly, P.N.; Shaffer, A.L.; Wright, G.W.; Xiao, W.; Yang, Y.; Mathews Griner, L.A.; Guha, R.; Shinn, P.; Keller, J.M.; et al. Blockade of oncogenic IkappaB kinase activity in diffuse large B-cell lymphoma by bromodomain and extraterminal domain protein inhibitors. Proc. Natl. Acad. Sci. USA 2014, 111, 11365-11370. [CrossRef]

161. Ellis, L.; Pan, Y.; Smyth, G.K.; George, D.J.; McCormack, C.; Williams-Truax, R.; Mita, M.; Beck, J.; Burris, H.; Ryan, G.; et al. Histone deacetylase inhibitor panobinostat induces clinical responses with associated alterations in gene expression profiles in cutaneous T-cell lymphoma. Clin. Cancer Res. 2008, 14, 4500-4510. [CrossRef] [PubMed]

162. Batty, N.; Malouf, G.G.; Issa, J.P. Histone deacetylase inhibitors as anti-neoplastic agents. Cancer Lett. 2009, 280, 192-200. [CrossRef] [PubMed]

163. Vilas-Zornoza, A.; Agirre, X.; Abizanda, G.; Moreno, C.; Segura, V.; De Martino Rodriguez, A.; Jose-Eneriz, E.S.; Miranda, E.; Martin-Subero, J.I.; Garate, L.; et al. Preclinical activity of LBH589 alone or in combination with chemotherapy in a xenogeneic mouse model of human acute lymphoblastic leukemia. Leukemia 2012, 26, 1517-1526. [CrossRef] [PubMed] 
164. Stubbs, M.C.; Kim, W.; Bariteau, M.; Davis, T.; Vempati, S.; Minehart, J.; Witkin, M.; Qi, J.; Krivtsov, A.V.; Bradner, J.E.; et al. Selective Inhibition of HDAC1 and HDAC2 as a Potential Therapeutic Option for B-ALL. Clin. Cancer Res. 2015, 21, 2348-2358. [CrossRef] [PubMed]

165. Newbold, A.; Falkenberg, K.J.; Prince, H.M.; Johnstone, R.W. How do tumor cells respond to HDAC inhibition? FEBS J. 2016, 283, 4032-4046. [CrossRef] [PubMed]

166. Roberts, K.G.; Yang, Y.L.; Payne-Turner, D.; Lin, W.; Files, J.K.; Dickerson, K.; Gu, Z.; Taunton, J.; Janke, L.J.; Chen, T.; et al. Oncogenic role and therapeutic targeting of ABL-class and JAK-STAT activating kinase alterations in Ph-like ALL. Blood Adv. 2017, 1, 1657-1671. [CrossRef]

167. Tanasi, I.; Ba, I.; Sirvent, N.; Braun, T.; Cuccuini, W.; Ballerini, P.; Duployez, N.; Tanguy-Schmidt, A.; Tamburini, J.; Maury, S.; et al. Efficacy of tyrosine kinase inhibitors in Ph-like acute lymphoblastic leukemia harboring ABL-class rearrangements. Blood 2019, 134, 1351-1355. [CrossRef]

Publisher's Note: MDPI stays neutral with regard to jurisdictional claims in published maps and institutional affiliations.

(C) 2020 by the authors. Licensee MDPI, Basel, Switzerland. This article is an open access article distributed under the terms and conditions of the Creative Commons Attribution (CC BY) license (http://creativecommons.org/licenses/by/4.0/). 